\title{
Relationship between the molecular composition, visible light absorption, and health-related properties of smoldering woodsmoke aerosols
}

\author{
Lam Kam Chan ${ }^{1}$, Khanh Q. Nguyen ${ }^{1}$, Noreen Karim ${ }^{1}$, Yatian Yang ${ }^{1, a}$, Robert H. Rice ${ }^{1}$, Guochun He ${ }^{1}$, \\ Michael S. Denison ${ }^{1}$, and Tran B. Nguyen ${ }^{1}$ \\ ${ }^{1}$ Department of Environmental Toxicology, University of California Davis, Davis, CA 95616, USA \\ ${ }^{a}$ now at: Department of Biochemistry and Molecular Medicine, UC Davis School of Medicine, Sacramento, CA, USA
}

Correspondence: Tran B. Nguyen (tbn@ucdavis.edu)

Received: 21 August 2019 - Discussion started: 10 September 2019

Revised: 22 November 2019 - Accepted: 8 December 2019 - Published: 17 January 2020

\begin{abstract}
Organic aerosols generated from the smoldering combustion of wood critically impact air quality and health for billions of people worldwide; yet, the links between the chemical components and the optical or biological effects of woodsmoke aerosol (WSA) are still poorly understood. In this work, an untargeted analysis of the molecular composition of smoldering WSA, generated in a controlled environment from nine types of heartwood fuels (African mahogany, birch, cherry, maple, pine, poplar, red oak, redwood, and walnut), identified several hundred compounds using gas chromatography mass spectrometry (GCMS) and nano-electrospray high-resolution mass spectrometry (HRMS) with tandem multistage mass spectrometry $\left(M^{n}\right)$. The effects of WSA on cell toxicity as well as gene expression dependent on the aryl hydrocarbon receptor $(\mathrm{AhR})$ and estrogen receptor (ER) were characterized with cellular assays, and the visible mass absorption coefficients $\left(\mathrm{MAC}_{\mathrm{vis}}\right)$ of WSA were measured with ultraviolet-visible spectroscopy. The WSAs studied in this work have significant levels of biological and toxicological activity, with exposure levels in both an outdoor and indoor environment similar to or greater than those of other toxicants. A correlation between the HRMS molecular composition and aerosol properties found that phenolic compounds from the oxidative decomposition of lignin are the main drivers of aerosol effects, while the cellulose decomposition products play a secondary role; e.g., levoglucosan is anticorrelated with multiple effects. Polycyclic aromatic hydrocarbons (PAHs) are not expected to form at the combustion temperature in this work, nor were they observed above the detection limit; thus,
\end{abstract}

biological and optical properties of the smoldering WSA are not attributed to PAHs. Syringyl compounds tend to correlate with cell toxicity, while the more conjugated molecules (including several compounds assigned to dimers) have higher $\mathrm{AhR}$ activity and $\mathrm{MAC}_{\mathrm{vis}}$. The negative correlation between cell toxicity and AhR activity suggests that the toxicity of smoldering WSA to cells is not mediated by the AhR. Both mass-normalized biological outcomes have a statistically significant dependence on the degree of combustion of the wood. In addition, our observations support the fact that the visible light absorption of WSA is at least partially due to charge transfer effects in aerosols, as previously suggested. Finally, $\mathrm{MAC}_{\mathrm{vis}}$ has no correlation with toxicity or receptor signaling, suggesting that key chromophores in this work are not biologically active on the endpoints tested.

\section{Introduction}

The combustion of wood from, for example, residential fireplaces, forest fires, and prescribed burns is a large source of fine particulate matter $\left(\mathrm{PM}_{2.5}\right)$ in the United States and much of the world (Rogge et al., 1998; EPA, 2003; Mazzoleni et al., 2007; Park et al., 2007; Swiston et al., 2008; Zhang et al., 2013), particularly in winter when woodsmoke aerosol (WSA) can account for the majority of organic carbon and up to $90 \%$ of $\mathrm{PM}_{2.5}$ regionally (Rogge et al., 1998; Gorin et al., 2006; Kleeman et al., 2008; NYSERDA, 2008). In an indoor environment, the incomplete combustion of solid fuels 
(64\%-95\% wood usage in rural India at, but also dung and crops; Menon, 1988) is the main source of indoor air pollution exposure to roughly 3 billion people worldwide (WHO, 2011). This indoor WSA exposure occurs mostly in developing nations and mostly to women and children, possibly accounting for the highest burden of environmental disease globally (Ezzati and Kammen, 2002; WHO, 2002; Smith and Mehta, 2003).

Multiple factors impact the combustion chemistry, such as the wood composition (lignin / cellulose fractions, lignin $\mathrm{H} / \mathrm{G} / \mathrm{S}$ composition, natural monomers such as resins, waxes, sugars), water fraction, environmental conditions, and other factors, which in turn impact the aerosol composition and effects. During a typical fire, the high-intensity but short initial period of flaming combustion is correlated with $\mathrm{CO}_{2}$ production and emissions that rise to higher altitudes. In contrast, the low-intensity but long period of smoldering combustion is correlated with $\mathrm{CO}$ and other products of incomplete combustion, and emissions remain closer to the ground (Andreae and Merlet, 2001) where they are more likely inhaled. Smoldering combustion, which produces a higher quantity of particles and most of the organic species in a fire (Einfeld et al., 1991; Yokelson et al., 1997; Bertschi et al., 2003), is responsible for the majority of biomass consumption during prescribed burns, residential wood burning, cigarette smoke, and fires from tropical and temperate forests and deforestation areas (Standley and Simoneit, 1990; Ward et al., 1992; Yokelson et al., 1997; Simoneit et al., 2000; Ohlemiller, 2002; Rabelo et al., 2004). Due to the high toxicant production, the emissions from smoldering combustion are recommended to be used to assess health exposure (Morawska and Zhang, 2002). This work focuses on the organic aerosols generated from the smoldering combustion of wood in a controlled laboratory setting.

The significant adverse health effects of WSA on endpoints such as mortality, morbidity, respiratory disease, and cancer, among others, are well-documented and are characterized to be as serious as, if not more serious than, other sources of particulate matter (Lewis et al., 1988; Zelikoff et al., 2002; Boman et al., 2003; Kubátová et al., 2006; Orozco-Levi et al., 2006; Lewtas, 2007; Swiston et al., 2008; Danielsen et al., 2011). For example, organic extracts of particulate matter with high WSA content were found to be approximately 30 times more potent than cigarette smoke condensate in a tumor induction assay (Cupitt et al., 1994). Yet, it is not clear whether the health-related effects of WSA organics can be attributed to toxicants other than the well-studied polycyclic aromatic hydrocarbons (PAHs), such as the multifunctional aldehydes, ketones, phenols, and organic nitrogen, organic acids (Hedberg et al., 2002) that are also present in WSA with largely unknown biological effects. Previous bulk analyses have shown that the emissions of total particulate matter and PAHs depend on the wood type and burn conditions (Maga and Chen, 1985; Bølling et al., 2009; Nyström et al., 2017). High-resolution mass spectrometry (HRMS) anal- yses have offered insight into the complex molecular composition of aerosols from biomass combustion (Smith et al., 2008; Laskin et al., 2009; Lin et al., 2016, 2017; Fleming et al., 2018). However, the links between the chemical origin and macroscopic endpoints are still poorly understood. This work focuses on two critical gaps in knowledge surrounding woodsmoke (Naeher et al., 2007): the fundamental understanding of (1) how different types of wood and burn conditions affect the molecular composition and (2) relationships between the aerosol's properties and its chemical composition.

We measured the total cellular toxicity effects of smoldering WSA. In addition, the Ah receptor (AhR) and estrogen receptor (ER) are known to play critical regulatory roles in mediating the biological and toxicological effects of diverse environmental chemicals. As wood combustion produces PAH-like compounds and phenolic compounds, classes of chemicals that are known to activate the AhR and/or ER signaling pathways (Denison and Nagy, 2003; Krüger et al., 2008; Stejskalova et al., 2011; Li et al., 2012; Cipolletti et al., 2018), we measured the AhR and ER activities of smoldering WSA. Alongside biological effects, we also studied the potential chromophores responsible for the visible light absorption of smoldering WSA. The combustion of wood (and other biomass) is known to produce "brown carbon" aerosols (Andreae and Gelencser, 2006), which absorb light in the troposphere and appear yellow or brown to the eye. Although most of the absorption of WSA and other biomass burning aerosols is due to elemental carbon (soot) in the atmosphere, the organic aerosols such as in smoldering WSA represent a secondary but not insignificant fraction (Kirchstetter and Thatcher, 2012; Washenfelder et al., 2015).

\section{Experimental design}

\subsection{Smoldering combustion woodsmoke aerosols}

Woodsmoke aerosol (WSA) samples were prepared in a $40 \mathrm{~L}$ smoldering combustion chamber (Fig. 1) that is fitted with Teflon tubing. The relative humidity $(\mathrm{RH})$ for the combustion was set to $\sim 40 \%$, as verified by a membrane humidity probe (Vaisala Inc.), chosen to be consistent with the $\mathrm{RH}$ range found in some indoor environments (Salonvaara et al., 2004; Irulegi et al., 2017) where residential wood burning may occur and with the daytime RH that is correlated with wildfire events (highest burned areas at RH $38 \%-42 \%$ ) (Flannigan and Harrington, 1988; Piñol et al., 1998). Humidified ultra-zero air in the chamber was achieved by combining $\mathrm{a} \sim 1.5 \mathrm{~L} \mathrm{~min}^{-1}$ humid flow through a wet-wall humidifier with $\mathrm{a} \sim 2.5 \mathrm{~L} \mathrm{~min}^{-1}$ dry flow from a high-pressure cylinder (Airgas UZA: $20 \%-22 \% \mathrm{O}_{2}$ in $\mathrm{N}_{2}, 2$ ppm $\mathrm{H}_{2} \mathrm{O}, 1 \mathrm{ppm}$ $\mathrm{CO}_{2}, 1 \mathrm{ppm} \mathrm{CO}, 0.1 \mathrm{ppm}$ total hydrocarbons) through flow restrictors. 


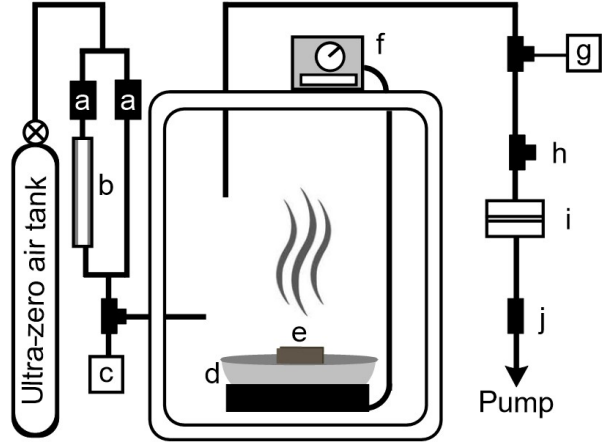

Figure 1. Simplified diagram of smoldering combustion chamber. Key: (a) pressure flow restrictors with different flow rates each to control humidity; (b) humidifier tube; (c) relative humidity probe; (d) heating mantle; (e) wood fuel blocks; (f) temperature controller; (g) thermocouple temperature measurement; (h) vent; (i) aerosol filter collection apparatus; (j) vacuum flow restrictor.

Heartwood samples of nine types of wood (African mahogany, birch, cherry, maple, pine, poplar, red oak, redwood, and walnut) were purchased from a lumber store local to Davis, $\mathrm{CA}$, and were cut into $4 \mathrm{~cm} \times 2 \mathrm{~cm} \times 1 \mathrm{~cm}$ blocks using a blade cleaned with isopropanol between each use. The subset of wood species selected are a combination of softwoods (redwood, pine) and hardwoods that can be found in North American forests (Burns and Honkala, 1990) and are often used for firewood or for building homes and furniture. Approximately two wood blocks with an average mass of $2.5 \mathrm{~g}$ each were used for every burn with a combustion temperature of $330^{\circ} \mathrm{C}$, which produced a thick white smoke from the smoldering process. After $15 \mathrm{~min}$ of combustion, aerosols were collected from the center of the chamber approximately $15-20 \mathrm{~cm}$ above the fuel source for $25 \mathrm{~min}$ with a polyvinylidene fluoride filter (Millipore Sigma, $0.65 \mu \mathrm{m}$ pore size) and a flow rate of approximately $2 \mathrm{~L} \mathrm{~min}^{-1}$ (the remaining flow is discarded through the vent). An average of $85 \%$ by mass of the fuel source was burned. The temperature at the location immediately upstream of aerosol collection was approximately $25^{\circ} \mathrm{C}$. The tubing in contact with aerosols and the filter collection apparatus was cleaned between each burn using isopropanol. Multiple (approximately three) burns of each wood type were performed, with reproducible results.

The WSA samples were gravimetrically analyzed and, if not used immediately, vacuum-sealed in polyethylene filter holders and stored at $-10^{\circ} \mathrm{C}$. Prior to analyses, WSAs were extracted in solvent using a mixture of $1: 1$ ultrapure water and acetonitrile with $30 \mathrm{~min}$ room-temperature agitation on an orbital shaker (IKA Inc.) at $1000 \mathrm{rpm}$. Each extraction used the required solvent to achieve a mass concentration of $5 \mathrm{mg} \mathrm{mL}^{-1}$, depending on the WSA mass collected, and was diluted for analyses as necessary.

\subsection{Molecular composition analysis}

Diluted WSA extracts $\left(100 \mu \mathrm{g} \mathrm{mL}^{-1}\right)$ were analyzed for organic molecular composition using a linear trap quadrupole Orbitrap (LTQ-Orbitrap) mass spectrometer (Thermo Corp.) at a mass-resolving power of $\sim 100000 \mathrm{~m} / \Delta \mathrm{m}$ at $\mathrm{m} / z 200$. The WSA extracts were directly infused into a capillary nano-electrospray ion source (ESI, $50 \mu \mathrm{m}$ fused-silica capillary tip, $4 \mathrm{kV}$ spray voltage, $275^{\circ} \mathrm{C}$ capillary temperature, $15 \mu \mathrm{L} \mathrm{min}^{-1}$ flow), and the spectra were taken at a mass range of $m / z 50-1000$ in the positive ion mode. Ionization mechanisms in the positive-ion-mode ESI include protonation $\left([\mathrm{M}+\mathrm{H}]^{+}\right.$ions) and/or sodiation $\left([\mathrm{M}+\mathrm{Na}]^{+}\right.$ions). An external 11-point mass calibration in the $m / z$ range of 100 600 was performed using a variety of analytical standard solutions (ESI-L tuning mix, amine mixture, and others; Supelco Inc.) immediately prior to the MS analysis such that the mass accuracy is adjusted to be approximately $1 \mathrm{ppm}$ for standard compounds. Insights into molecular structure were obtained using collision-induced dissociation (CID) multistage tandem mass spectrometry $\left(\mathrm{MS}^{n}\right.$, stages $\left.2-4\right)$ in the LTQ-Orbitrap for ions that have an adequate signal. CID energy was tuned for each mass so that the normalized precursor ion had $10 \%-20 \%$ abundance, and neutral or radical losses were analyzed using the Thermo Xcalibur software suite.

The sample mass spectra with a signal-to-noise ratio $(S / N)>3$ were processed by subtracting the background mass spectra of the blank filter extracts, deconvoluted with a quadratic fit model and deisotoped using Decon2LS tools (freeware from PNNL), mass-corrected with the external calibration curve, and assigned to molecular formulas using a custom MATLAB protocol based on heuristic mass filtering rules (Kind and Fiehn, 2007) and Kendrick mass (KM) defect analysis (Kendrick, 1963; Roach et al., 2011) with a KM base of $\mathrm{CH}_{2}$. Correlations with HRMS peaks are performed using MATLAB's linear regression model fitlm. Least-squares fit results with coefficients $\left(R^{2}\right)$ greater than 0.4 having slopes in either direction are reported.

The less polar, higher-volatility components of WSA were extracted using ethyl acetate at $100 \mu \mathrm{gL}^{-1}$ and analyzed with gas chromatography mass spectrometry (GC-MS) on an Agilent $6890 \mathrm{GC}$ and 5973 MS detector using an HP5 MS column $(30 \mathrm{~m} \times 250 \mu \mathrm{m} \times 0.25 \mu \mathrm{m})$ and the following temperature program: $50{ }^{\circ} \mathrm{C}(0.5 \mathrm{~min}$ hold $), 12{ }^{\circ} \mathrm{C} \mathrm{min}{ }^{-1}$ until $260^{\circ} \mathrm{C}$ (12 min hold). An EPA-610 method for PAHs (US EPA, 2005) and a PAH-certified calibration standard (TraceCERT, 16 components) were also used to verify if the WSA contained PAHs. The analytes were identified by their electron ionization fragmentation at $70 \mathrm{eV}$ - the spectra were compared to those from the GC-MS library from the National Institute of Standards and Technology. 


\subsection{Mass absorption coefficient}

The visible light absorption of WSA extracts was measured using a dual-beam ultraviolet-visible (UV-Vis) spectrophotometer (UV-1800, Shimadzu Corp.) and $1 \mathrm{~cm}$ quartz cuvettes at multiple extract concentrations. The per-gram light absorption of WSA extracts was calculated as a mass absorption coefficient (Moosmüller et al., 2011):

$\operatorname{MAC}(\lambda)=\frac{A(\lambda) \times \ln (10)}{C \times L}$,

where $A(\lambda)$ is the wavelength-dependent absorbance of the WSA extract, $C$ is the extract concentration $\left(0.005 \mathrm{~g} \mathrm{~mL}^{-1}\right)$, and $L$ is the pathlength of the light absorption $(1 \mathrm{~cm})$. To account for the wavelength dependence of MAC and compare between the WSA extracts in this study, we used an average MAC that was integrated in the visible region:

$\mathrm{MAC}_{\mathrm{vis}}=\frac{1}{700 \mathrm{~nm}-400 \mathrm{~nm}} \int_{400 \mathrm{~nm}}^{700 \mathrm{~nm}} \operatorname{MAC}(\lambda) \mathrm{d} \lambda$.

The absorption spectra (Fig. S1 in the Supplement) of the WSA extracts in this study are consistent with other ambient brown carbon spectra, wherein a featureless tailing absorption is observed into the visible wavelengths. As this work is focused on visible-light-absorbing chromophores, the UV portion of the brown carbon absorption was not examined. $\mathrm{MAC}_{\text {vis }}$ values determined at multiple extract concentrations varied less than $5 \%$ (Fig. S2).

\subsection{Cell toxicity bioassay}

Human epidermal keratinocytes were used to determine the toxicity of WSA. Keratinocytes can be found naturally in the upper respiratory tract, oral cavity, and in the trachea as a response to air pollution, cigarette smoke, and woodsmoke inhalation exposure (Plamenac et al., 1979b, a; Lee et al., 1994; Moran-Mendoza et al., 2008). Moreover, they have been shown to be a useful model for responses common to epithelial cells (Rhim, 1989; Neugebauer et al., 1996; Rogers et al., 2001). When exposed to toxic xenobiotic compounds, keratinocytes form an envelope of isopeptide cross-linked protein at the plasma membrane (Rice and Green, 1979). The cross-linking can be induced by permeabilization of the cells, permitting a rise in cytosolic calcium ions that activates the membrane-bound transglutaminase TGM1 and results in cell death. The protein content from envelope formation serves as a quantitative biomarker of cell damage from toxic exposure.

Briefly, cells were cultured and assayed as follows: spontaneously immortalized keratinocytes (SIK, passages 25-35) were serially cultivated in a 2:1 mixture of Dulbecco-Vogt Eagle's and Ham's F-12 media supplemented with fetal bovine serum (FBS) (5\%), hydrocortisone $\left(0.4 \mu \mathrm{g} \mathrm{mL}^{-1}\right)$, epidermal growth factor $\left(10 \mathrm{ng} \mathrm{mL}^{-1}\right)$, insulin $\left(5 \mu \mathrm{gL}^{-1}\right)$, transferrin $\left(5 \mu \mathrm{gL}^{-1}\right)$, and $0.18 \mathrm{mM}$ adenine (Allen-Hoffmann and Rheinwald, 1984; Rice et al., 1993). SIK cultures have a single chromosomal aberration that permits continuous growth throughout the range of passages employed while altering their behavior only minimally (Rice et al., 1993). After reaching confluence in 24 well plates, the cell cultures were incubated in a medium lacking an epidermal growth factor for $2 \mathrm{~d}$. Cultures were then incubated for $48 \mathrm{~h}$ with extracts of WSA $\left(5 \mathrm{mg} \mathrm{mL}^{-1}\right.$ in $1: 1 \mathrm{v} / \mathrm{v}$ water : acetonitrile, $15-240 \mu \mathrm{L}$ ) in the concentration range of 0.23 to $3.75 \mathrm{mg} \mathrm{mL}^{-1}$ in a total well volume of $320 \mu \mathrm{L}$ to increase the assay sensitivity while conserving cell viability. After incubation, the medium was discarded, and the cultures were further incubated for $24 \mathrm{~h}$ in an aqueous solution of $2 \%$ sodium dodecyl sulfate, $20 \mathrm{mM}$ dithiothreitol, and $50 \mathrm{mM}$ Tris buffer ( $\mathrm{pH} 8)$ at $37^{\circ} \mathrm{C}$. The envelopes from each well were isolated by centrifugation, rinsed three times in $0.1 \%$ sodium dodecyl sulfate, and assayed for relative protein content with bicinchoninic acid, quantified colorimetrically at a wavelength of $495 \mathrm{~nm}$ (Smith et al., 1985). As the protein structures of SIK cells exposed to WSA were isolated during the washing process, no interference from WSA absorption occurs in the colorimetric analysis. WSA extracts were assayed at each concentration in triplicate. Blank controls (extracted blank filter) and solvent controls did not result in envelope formation or the inhibition of envelope formation. Ionophore X5375, which is known to induce envelope formation in the large majority of cells (Rice and Green, 1979), was used as the positive control.

The half-maximal effective concentration $\left(\mathrm{EC}_{50}\right)$ of the WSA extract that induced a cell toxicity response halfway between the baseline and the maximum activity was obtained using concentration-response curves fitted in Origin software with adjusted $R^{2}>0.94$. The $\mathrm{EC}_{50}$ uncertainties were propagated from fit uncertainties and the standard deviations of triplicate analyses. Individual concentrationresponse curves and fits for the WSA extracts are shown in Fig. S3.

\subsection{Aryl hydrocarbon receptor (AhR) and estrogen receptor (ER) bioassays}

Screening of WSA extracts for AhR- or ER-active compounds was carried out using recombinant mouse hepatoma (H1L6.1c2) cells containing a stably integrated AhRresponsive luciferase reporter gene plasmid (pGudLuc6.1) and human breast carcinoma (VM7Luc4E2) cells containing a stably integrated ER-responsive luciferase reporter gene plasmid (pGudLuc7ere), as previously described (He et al., 2014; Brennan et al., 2016). Briefly, for AhR analysis, H1L6.1c2 cells in growth medium (alpha minimal essential media (aMEM) containing $10 \%$ FBS) were plated (75000 cells per well) into white, clear-bottomed 96-well tissue culture plates and incubated at $37^{\circ} \mathrm{C}$ for $24 \mathrm{~h}$ prior to the addition of WSA extracts. For ER analysis, VM7Luc4E2 
cells were switched from maintenance medium (aMEM containing $10 \% \mathrm{FBS}$ ) to estrogen-stripped medium (phenol redfree aMEM containing $10 \%$ charcoal-stripped FBS), incubated for $3 \mathrm{~d}$ at $37^{\circ} \mathrm{C}$ before plating into white, clearbottomed 96-well tissue culture plates at a density of 75000 cells per well, and further incubated at $37^{\circ} \mathrm{C}$ for $24 \mathrm{~h}$ prior to chemical addition. Cells were incubated with $1 \mu \mathrm{L}$ of dimethyl sulfoxide (DMSO) solvent $(1 \%, v / v)$, the reference standard dissolved in DMSO (2,3,7,8-tetrachlorodibenzo- $p$ dioxin (TCDD) for H1L6.1.c2 cells and 17 $\beta$-estradiol (E2) for VM7Luc4E2 cells), acetonitrile solvent, or WSA extract for $24 \mathrm{~h}$.

After incubation, cells were visually inspected for signs of toxicity, rinsed twice with phosphate-buffered saline, followed by the addition of Promega cell lysis buffer, and shaken for $20 \mathrm{~min}$ at room temperature to allow for complete cell lysis. Luciferase activity in each well was measured by using an Orion microplate luminometer as previously described (He et al., 2014). Luciferase activity was corrected for background activity in DMSO- and acetonitrile-treated cells and values (in relative light units, RLUs) expressed as a percent of the luciferase activity obtained with the maximally inducing concentration of TCDD or E2. All incubations and analyses were performed in triplicate. TCDD bioanalytical equivalents (BEQs) for AhR-active samples were determined by comparison of the luciferase activity of the sample extract to that in a TCDD concentration-response curve, as described elsewhere (Baston and Denison, 2011), and shown in Fig. S4. The relative magnitude of AhR and ER induction by WSA $\left(5 \times 10^{-6} \mathrm{~g}\right.$ of original material in each plate well) was normalized to the equivalent level of AhR and ER luciferase gene induction from the TCDD and ER concentration-response curves, respectively, on a gram per gram basis. The uncertainties in AhR and ER relative activity were propagated from the uncertainties in the triplicate determinations and the reference calibration concentrationresponse curves.

\section{Results and discussion}

\subsection{Biological and optical properties of WSA}

Table 1 shows cell toxicity, AhR activity, ER activity, and $\mathrm{MAC}_{\mathrm{vis}}$ results for the nine types of WSA extracts studied in this work, normalized by the mass of the original aerosol material. The results provide a clear indication that this type of complex mixture can affect macromolecular targets in cells. An important question is how relevant the smoldering WSA findings are to health effects from actual exposure. Although no assay will successfully reproduce the in vivo environment, i.e., exposure to approximately 40 different cell types in the respiratory tract, distribution of toxicants throughout the bloodstream to major organs, and either deactivation or activation by metabolism, these (and other) in vitro results are useful as an estimation of risk. Considering toxicity in an outdoor environment such as a wildfire event, $\mathrm{PM}_{2.5}$ concentrations in excess of $300 \mathrm{\mu g} \mathrm{m}^{-3}$ can be observed in surrounding areas (Wu et al., 2006; Wegesser et al., 2009) and up to $2.7 \mathrm{mg} \mathrm{m}^{-3}$ near the burn site (Adetona et al., 2011). As much of the aerosol comes from the first and second smoldering phases (Alves et al., 2011), realistic exposure to smoldering WSA in cities surrounding a fire can be $100 \mu \mathrm{g} \mathrm{m}^{-3}$. Assuming a typical pulmonary tidal volume of $500 \mathrm{~mL}$ for adults (Beardsell et al., 2009) and the cell toxicity $\mathrm{EC}_{50}$ of red oak smoldering WSA, we estimate that a human adult would take $\sim 2175$ breaths to reach the $\mathrm{EC}_{50}$ value. As a normal respiratory rate for an adult at rest is 12 breaths per minute (Carey et al., 2005), the $\mathrm{EC}_{50}$ limit is reached after $3 \mathrm{~h}$ of woodsmoke exposure, yet residents near fires can be exposed to the smoke for many days (Wegesser et al., 2009). The acute exposure health risk of residential wood burning in an indoor environment is more severe. $\mathrm{PM}_{2.5}$ concentrations around cookstoves are high (e.g., $1.8 \mathrm{mg} \mathrm{m}^{-3}$ ) (Chowdhury et al., 2012) such that the $\mathrm{EC}_{50}$ limit is reached in $\sim 120$ breaths or $10 \mathrm{~min}$, a highly plausible exposure duration that occurs almost daily for some people. The cell toxicity results are consistent with epidemiological and toxicological evidence for negative human health impacts of WSA (Naeher et al., 2007, and references therein). In light of previous findings that smoldering combustion at medium temperature produces particles that are more toxic than those from hightemperature combustion or complete combustion (Bølling et al., 2012, and references therein), the results from this work suggest that the smoldering fraction of WSA could significantly contribute to the overall WSA health impacts.

The interpretation of the AhR activity of WSA is more complex. AhR (Denison and Heath-Pagliuso, 1998) is a ligand-activated transcription factor that mediates the biochemical and toxic effects of various well-recognized environmental toxicants, such as dioxins (Mandal, 2005; Denison et al., 2011) and PAHs (Machala et al., 2001; Barron et al., 2004; Billiard et al., 2006), but also a wide variety of other structurally diverse chemicals (Denison and Nagy, 2003; Nguyen and Bradfield, 2007; Petkov et al., 2010). However, AhR-dependent (i.e., dioxin-like) toxicity appears to be mediated only by dioxin-like chemicals (e.g., polyhalogenated dibenzo- $p$-dioxins, dibenzofurans, and biphenyls) and not all AhR agonists, the majority of which are metabolically inactivated. Determination of the presence of toxic AhR ligands in a sample requires extensive sample workup to isolate dioxinlike chemicals from the large number of nontoxic AhR-active chemicals. Thus, the AhR bioassay results for WSA in this work provide a measure of the overall ability of the extract to activate the AhR and AhR-dependent gene expression and do not provide a direct measure of AhR-dependent toxic potency. However, they do not rule out the presence of toxic AhR ligands; further sample isolation and analytical analysis would be needed to confirm the presence of dioxin-like chemicals in the WSA samples. The relatively high levels of 
Table 1. Results for cellular assays and visible light mass absorption coefficient $\left(\mathrm{MAC}_{\mathrm{vis}}\right)$ for WSA extracts. Lower EC $\mathrm{E}_{50}$ values correspond to higher toxicity. AhR and ER activities are expressed as bioequivalent (BEQ) values of calibrant compounds 2,3,7,8-tetrachlorodibenzo$p$-dioxin (TCDD) and 17 $\beta$-estradiol (E2), respectively. All aerosol properties reference the mass in grams of original WSA material that was tested. The concentration-response curves for the cell toxicity of different WSA (Fig. S3) and the receptor activity of TCDD and ER (Fig. S4) can be found in the Supplement.

\begin{tabular}{lrrrr}
\hline Wood sample & $\begin{array}{r}\text { Cell toxicity } \\
\mathrm{EC}_{50}(\mu \mathrm{g})\end{array}$ & $\begin{array}{r}\text { AhR activity } \\
\left(\mathrm{TCDD} \mathrm{BEQ}, \mathrm{gg}^{-1}\right)\end{array}$ & $\begin{array}{r}\text { ER activity } \\
\left(\mathrm{E} 2 \mathrm{BEQ}, \mathrm{gg}^{-1}\right)\end{array}$ & $\begin{array}{r}\mathrm{MAC}_{\mathrm{vis}} \\
\left(\mathrm{cm}^{2} \mathrm{~g}^{-1}\right)\end{array}$ \\
\hline Afr. mahogany & $250 \pm 20 \% \mathrm{a}$ & $2.5 \times 10^{-6} \pm 12 \%$ & $3.5 \times 10^{-9} \pm 15 \%$ & $2009 \pm 10 \%$ \\
Birch & $160 \pm 25 \%$ & $1.9 \times 10^{-7} \pm 13 \%$ & N.D. & $1645 \pm 10 \%$ \\
Cherry & $208 \pm 30 \%$ & $2.2 \times 10^{-7} \pm 12 \%$ & $3.5 \times 10^{-9} \pm 17 \%$ & $1387 \pm 10 \%$ \\
Maple & $160 \pm 20 \%$ & $1.3 \times 10^{-6} \pm 10 \%$ & $3.5 \times 10^{-9} \pm 10 \%$ & $1927 \pm 10 \%$ \\
Pine & $256 \pm 20 \%$ & $4.0 \times 10^{-6} \pm 25 \%$ & $1.8 \times 10^{-9} \pm 26 \%$ & $1477 \pm 10 \%$ \\
Poplar & $163 \pm 40 \%$ & $7.5 \times 10^{-7} \pm 14 \%$ & $1.5 \times 10^{-9} \pm 35 \%$ & $1557 \pm 10 \%$ \\
Red oak & $109 \pm 40 \%$ & $8.1 \times 10^{-8} \pm 16 \%$ & N.D. & $1094 \pm 10 \%$ \\
Redwood & $320 \pm 20 \%$ & $3.4 \times 10^{-6} \pm 10 \%$ & $3.6 \times 10^{-9} \pm 25 \%$ & $637 \pm 10 \%$ \\
Walnut & $320 \pm 20 \%$ & $4.0 \times 10^{-6} \pm 25 \%$ & $1.9 \times 10^{-9} \pm 30 \%$ & $1118 \pm 10 \%$ \\
\hline
\end{tabular}

a Table values are reported as the mean of repeated trials with uncertainty noted as a percent of the mean that has been propagated from multiple sources. ${ }^{b}$ Not detected (N.D.). Values are not significantly different than controls at this sample preparation protocol.

AhR-active chemicals observed in the WSA samples tested here could potentially lead to adverse effects via the ability of these compounds to stimulate the AhR-dependent expression of gene products such as cytochrome P4501A1, which can contribute to the metabolic activation of PAHs into their mutagenic form, as well as contribute to increased oxidative stress as a result of the production of reactive oxygen species as a byproduct of the CYP1A1 metabolism of endogenous and exogenous chemicals (Park et al., 1996; Nebert et al., 2000, 2004). Our results are also fairly consistent with the previous observation that WSA has a relative carcinogenesis potency of $1-6 \times 10^{-4}$ compared to pure benzo $[a]$ pyrene (Lewtas, 2007), another AhR ligand with well-recognized adverse health effects, although the lack of information about the specific wood fuels and burn conditions used in that study does not allow for direct comparisons to the WSA results presented here.

The ER activity assay results demonstrate the presence of relatively low levels of endocrine-active chemicals (EACs) or low-potency EACs in WSA to which inhalation exposure could occur. WSA exposure risk would need to take into account a variety of aspects, including the ambient dose and the physicochemical characteristics and metabolic stability of the responsible EACs. In terms of ecological risk, the concentration of WSA chemicals from partitioning into water would be expected to be low, and thus it would be unlikely to produce endocrine effects in wildlife from this route. In terms of exposure risk to humans, the comparison is challenging because the concentrations of known EACs are not as widely measured in atmospheric aerosols as the "usual suspects" like PAHs, and many EACs still remain to be identified. Additionally, the ability of a chemical to act as an EAC in vitro does not address whether it can produce adverse endocrine-related health effects in vivo (i.e., whether it acts as an endocrine disruptor chemical, EDC). In an indoor environment the WSA concentration can be higher than outdoors, but the exposure from using cookstoves is not as sustained over many hours or days, such as that which occurs with a wildfire, and is not nearly as continual as exposure to ER-active chemicals from consumer or industrial products. It is possible that risks from WSA exposure may be comparable to other EACs and EDCs of concern in some situations.

Despite potential dissimilarities in chemical composition, it can be instructive to compare the total AhR and ER activity of smoldering WSA to those measured for ambient particulate matter. Utilizing similar cell-based bioassays, $\mathrm{PM}_{1}$ collected from rural and urban traffic sites in Switzerland was found to have AhR activity of $0.5-2 \times 10^{-6} \mathrm{~g}$ TCDD EQs $(\mathrm{g} \mathrm{PM})^{-1}$ and ER activity of $2-23 \times 10^{-9} \mathrm{~g}$ E2 EQs $(\mathrm{g} \mathrm{PM})^{-1}$ (Wenger et al., 2009a, b). Similarly, $\mathrm{PM}_{10}$ collected from downtown Toronto, Canada, was found to have AhR activity of $0.04-1 \times 10^{-6} \mathrm{~g}$ TCDD EQs $(\mathrm{g} \mathrm{PM})^{-1}$ and ER activity of $\sim 10^{-6} \mathrm{~g}$ E2 EQs $(\mathrm{g} \mathrm{PM})^{-1}$ (Clemons et al., 1998). PM of various size fractions from different polluted sites in the Czech Republic had AhR activity of 0.001$1 \times 10^{-6} \mathrm{~g}$ TCDD EQs $(\mathrm{g} \mathrm{PM})^{-1}$ and ER activity of $0.1-$ $20 \times 10^{-9}$ g E2 EQs (g PM) ${ }^{-1}$ (Novák et al., 2014). Organic PM in Wuhan, China, was found to have ER activity of $\sim 2$ $8 \times 10^{-7} \mathrm{~g} \mathrm{E}^{2} \mathrm{EQs} \mathrm{g}{ }^{-1}$, depending on whether the PM was collected on sunny or foggy days (Wang et al., 2004). In comparison, the AhR activities of smoldering WSA in this work are within the range of PM from urban and industrial sites, while the ER activities are similar to some types of urban and industrial PM but a factor of $10^{2-3}$ lower than others. Wenger et al. (2009a) also found the total concentration of AhR agonists to be much higher than concentrations for the tradi- 
tional AhR agonists such as polychlorinated dibenzodioxins (PCDDs) and polychlorinated dibenzofurans (PCDFs), suggesting a diversity of AhR-active ligands in ambient PM and further supporting the notion that AhR can bind and be activated by a wide range of structurally diverse chemicals in the environment (Denison and Nagy, 2003; DeGroot et al., 2011; Stejskalova et al., 2011). Furthermore, it has been reported that $\mathrm{PM}_{2.5}$ exposure can affect sperm development in humans (Wu et al., 2017; Lao et al., 2018), particularly in men exposed to wintertime air pollution where WSA is high (Selevan et al., 2000); however, whether ER- and/or AhR-active chemicals present in smoldering WSA could contribute to these endocrine effects remains an open question.

The relative biological effects of WSA from different types of wood is a novel insight from this study to the best of our knowledge. From Table 1, it appears that the WSA extracts that are highly active in the AhR bioassay do not necessarily kill cells, and vice versa. In fact, we found that the cell toxicity and AhR activity of woodsmoke WSA were negatively correlated with a fairly strong adjusted $R^{2}$ coefficient of 0.74 (Fig. S5a). This suggests that the smoldering WSAs analyzed in these bioassays contain compounds whose cytotoxic activity is not AhR-mediated but may be classified among the myriad other AhR-active chemicals that have been identified (Denison and Nagy, 2003; Galati and O'brien, 2004; Nguyen and Bradfield, 2007; DeGroot et al., 2011). We found that the biological effects of WSA have a moderate $\left(R^{2}>0.5\right)$ relationship with the percent by mass of the wood fuel that has been burned in a set duration of time (Fig. 2), which may be related to the lignin content and solvent-soluble monomers in the fuel (White, 2007). As all WSA effects have been normalized by mass, this indicates that the biological properties may be related to the degree of oxidation and/or degradation of the wood during the smoldering process. That said, we found no relationship between aerosol properties and the $\mathrm{O}$ : $\mathrm{C}$ ratio of the WSA compounds. This may be because even oxidative processes can fragment molecules in the wood in addition to functionalizing certain molecules with oxygenated moieties. This interesting relationship should be further explored with more focused studies.

The MAC values for different WSA in this work are within the range of organic-rich brown carbon (Updyke et al., 2012) and particulate matter from a smoldering fire (Patterson and McMahon, 1984) but lower than ambient brown carbon likely because $\sim 90 \%$ of that absorption comes from elemental carbon (Washenfelder et al., 2015). The MAC for the extracts in our study may also be lower than those extracted in less polar solvents such as acetone (Chen and Bond, 2010). Within the limited fuel types employed in this work, there does not appear to be an obvious correlation between $\mathrm{MAC}_{\mathrm{vis}}$ and wood hardness or percent of wood burned by weight $\left(R^{2} \sim 0.08\right)$, suggesting that the visible light absorption of the aerosols may depend on the more specific chemistry to form chromophoric constituents in the combustion. Further-

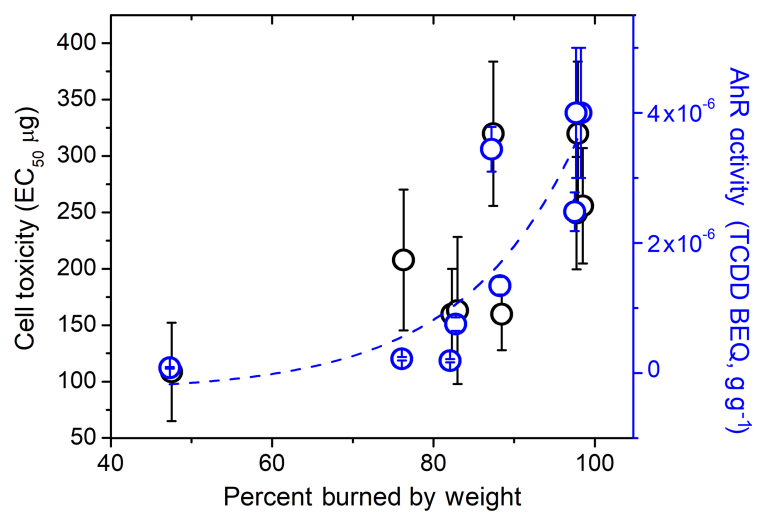

Figure 2. Relationship between cell toxicity and the AhR activity of smoldering WSA extracts with the percent of wood that has been burned at the time of aerosol collection.

more, the $\mathrm{MAC}_{\mathrm{vis}}$ values do not correlate with either cell toxicity (Fig. S5b, adj. $R^{2}=0.03$ ) or AhR activity (Fig. S5c, adj. $\left.R^{2}=-0.06\right)$, suggesting that chromophoric species in this work (e.g., specific conjugated compounds, charge transfer complexes) are not necessarily those producing these effects. In contrast, specific classes of chromophores from atmospheric aerosols in China have been found to have oxidative potential based on a chemical assay, which was suggested to be due to their PAH-like, quinone-like, or metallic constituents (Chen et al., 2019).

\subsection{Molecular composition of WSA and correlations with aerosol properties}

The chemical composition of aerosols from the oxygen-poor smoldering combustion or oxygen-free pyrolysis of lignocellulose material such as wood has been the subject of extensive study (Edye and Richards, 1991; Simoneit et al., 1993, 2000; McKenzie et al., 1994; Ingemarsson et al., 1998; Oros and Simoneit, 2001a, b; Simoneit, 2002; Hosoya et al., 2007b; Nunes et al., 2010), with many previous works focusing on the mid- to low-polarity constituents that can be analyzed by GC-MS. Low-intensity combustion abundantly forms phenolic derivatives with hydroxyphenyl $(\mathrm{H})$, guaiacyl $(\mathrm{G})$, and syringyl (S) units from the breakdown of lignin. Furan derivatives (e.g., furfurals), sugar anhydrides (e.g., levoglucosan, mannosan, galactosan), and other products are formed from the combustion of cellulose under a variety of conditions (Shafizadeh and Fu, 1973; Simoneit et al., 1999). PAHs are not expected to be formed at the $330^{\circ} \mathrm{C}$ combustion temperature in this work (Rhee and Bratzler, 1968; Sharma and Hajaligol, 2003), and indeed the GC-MS analysis using ethyl acetate solvent confirmed that PAHs were not observed above the detection limit (Table S1). If formed, PAHs might have ended up in tar-like material as opposed to the aerosols that were collected and tested. Thus, the biological activity and light absorption of the smoldering WSA 

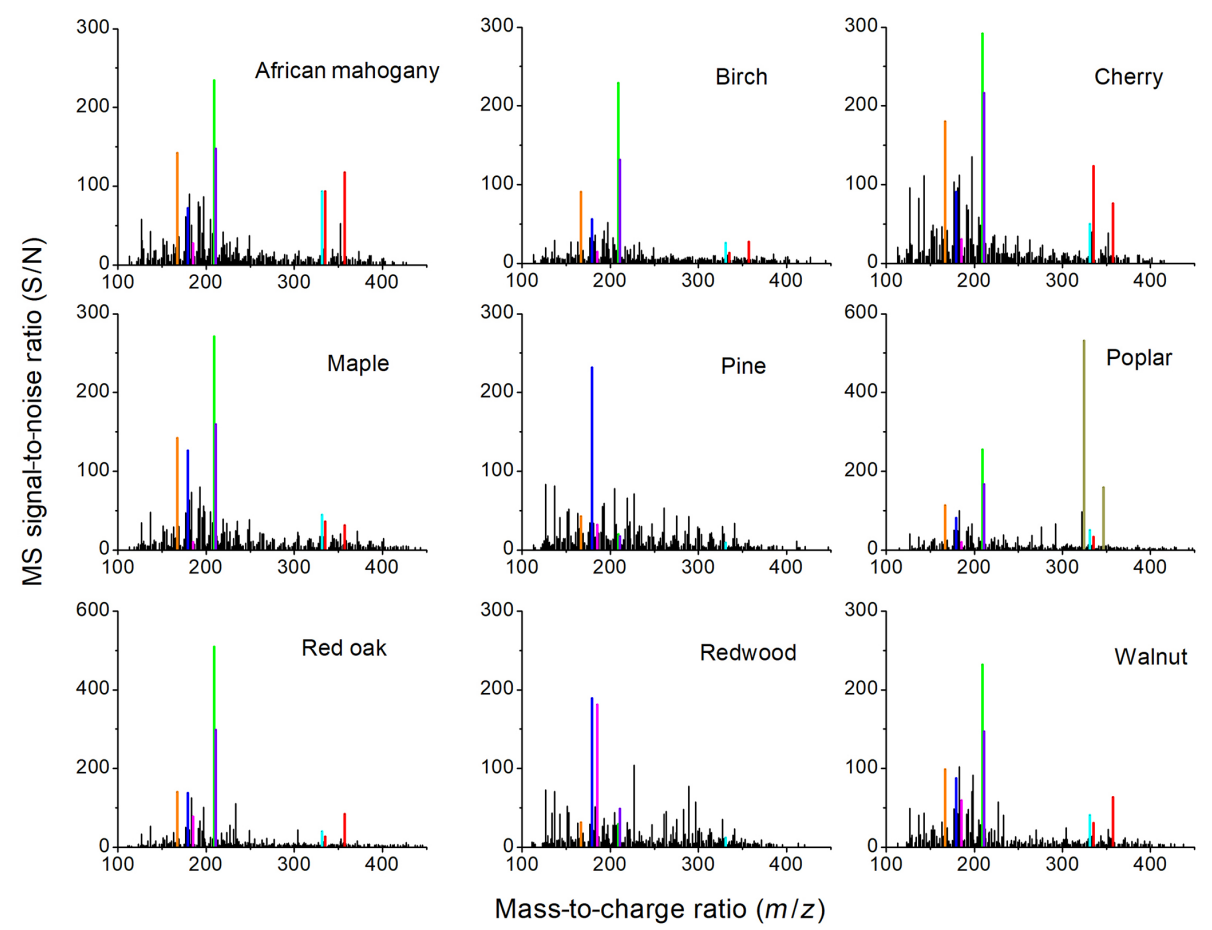

Figure 3. High-resolution mass spectra of WSA extracts in the study, taken at $100 \mu \mathrm{gL}^{-1}$ concentration. The color key for highlighted peaks with proposed assignments for the major species at each peak is as follows: orange $-\mathrm{C}_{9} \mathrm{H}_{10} \mathrm{O}_{3}$, acetovanillone, or homovanillin (protonated); blue $-\mathrm{C}_{10} \mathrm{H}_{10} \mathrm{O}_{3}$, coniferyl aldehyde (protonated); magenta $-\mathrm{C}_{6} \mathrm{H}_{10} \mathrm{O}_{5}$, levoglucosan, mannosan, or galactosan (sodiated); green $-\mathrm{C}_{11} \mathrm{H}_{12} \mathrm{O}_{4}$, sinapaldehyde (protonated); cyan $-\mathrm{C}_{18} \mathrm{H}_{18} \mathrm{O}_{6}$, G-vanillin dimer (protonated); red $-\mathrm{C}_{18} \mathrm{H}_{22} \mathrm{O}_{6}$, various $\mathrm{S}-\mathrm{G}$ dimers (protonated and sodiated); dark yellow $-\mathrm{C}_{20} \mathrm{H}_{21} \mathrm{NO}_{3}$, unknown alkaloid (protonated and sodiated).

in this work are not likely due to PAHs. However, we observed molecular formulas that could be assigned to PAHlike compounds (Fig. 4) from lignin decomposition. The GC-MS analysis identified sugar anhydrides, phenolic compounds, and alkane derivatives in the mid- to low-polarity fraction of the smoldering WSA (Fig. S6, Table S1), consistent with previous reports.

Figure 3 shows the positive-ion-mode HRMS spectra of WSA extracts, highlighting the more abundant constituents in the polar, lower-volatility fraction. $\mathrm{MS}^{n}$ analyses support the fact that the majority of smoldering WSA compounds are phenolic species (e.g., $\mathrm{CH}_{3} \mathrm{OH}$ losses, $\mathrm{H}_{2} \mathrm{O}$ losses, and phenyl ionic fragments) that have a variety of carbonyl, alcohol, alkenyl, acid, and other moieties. There are 300-400 peaks in each spectrum that are both over the limit of detection and that can be assigned to a molecular formula within 2 ppm mass accuracy. There are more than 700 unique peaks observed in all samples.

Figure 4 shows the chemical structures of select observed compounds. The compound with the highest abundance in most samples was sinapaldehyde $\left(\mathrm{C}_{11} \mathrm{H}_{12} \mathrm{O}_{4}\right.$; Fig. 3 green), except for the coniferous softwoods (pine and redwood) for which coniferaldehyde $\left(\mathrm{C}_{10} \mathrm{H}_{10} \mathrm{O}_{3}\right.$; Fig. 3 blue $)$ was the highest peak. This is consistent with the fact that coniferyl alcohol is the main polymer building block of softwood lignin, while sinapyl alcohol (to a higher extent) and coniferyl alcohol are both important building blocks of hardwood lignin (Graglia et al., 2015). We did not observe a high abundance of hydroxyphenyl (H) derivatives, (e.g., coumaraldehyde is $\sim 25$ times less abundant than sinapaldehyde on average), which is consistent with the fact that coumaryl alcohol is the dominant lignin building block in grasses instead of wood (Himmelsbach and Barton, 1980). Levoglucosan (and its isomeric sugar anhydrides; $\mathrm{C}_{6} \mathrm{H}_{10} \mathrm{O}_{5}$; Fig. 3 magenta) was also abundantly observed in HRMS, with the largest signal in redwood WSA, alongside its decomposition products such as methylfurfural, hydroxymethylfurfural, tetrahydrofuran derivatives, and others (Hosoya et al., 2007a; Lin et al., 2009).

High-molecular-weight compounds that were observed are tentatively assigned to dimers from phenolic G- and Sunit building blocks with various linkages (Fig. 4, bottom) according to previous observations (Goñi and Hedges, 1992; van der Hage et al., 1994; Guillén and Ibargoitia, 1999; Christensen et al., 2017), mechanistic feasibility (Beste, 2014), and $\mathrm{MS}^{n}$ evidence where available. The radical chemistry of lignin formation and combustion is probabilistic such that the diversity of isomers increases with molecular mass, so there are likely multiple structures possible for each larger molecular formula. For example, $\mathrm{C}_{14} \mathrm{H}_{14} \mathrm{O}_{4}$ is assigned to 
Select observed monomers

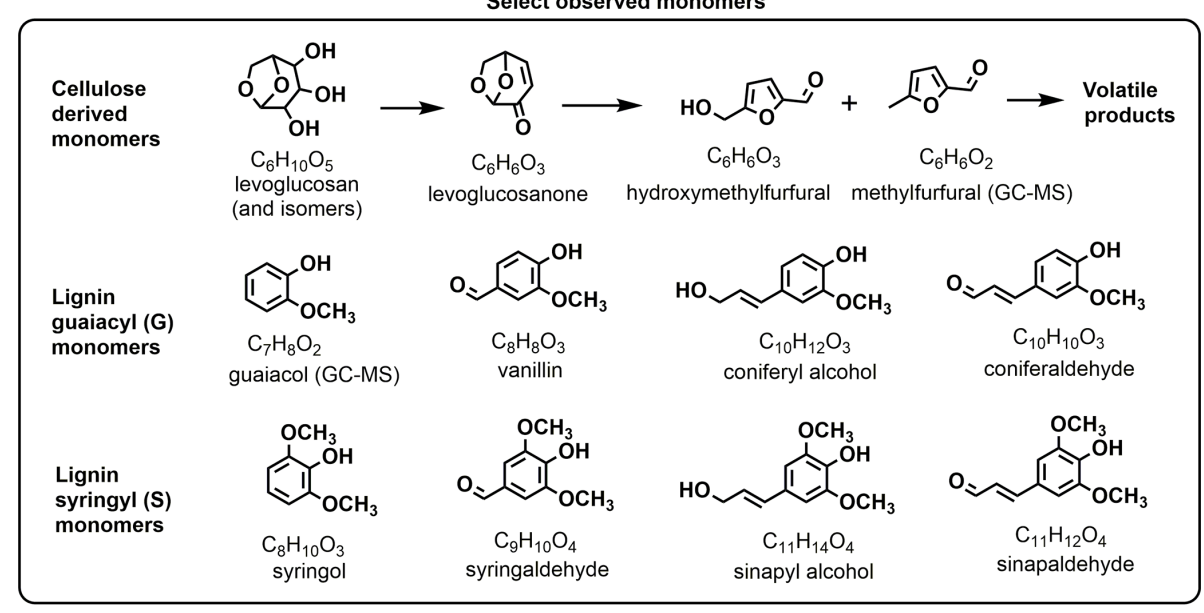

Select observed lignin dimers

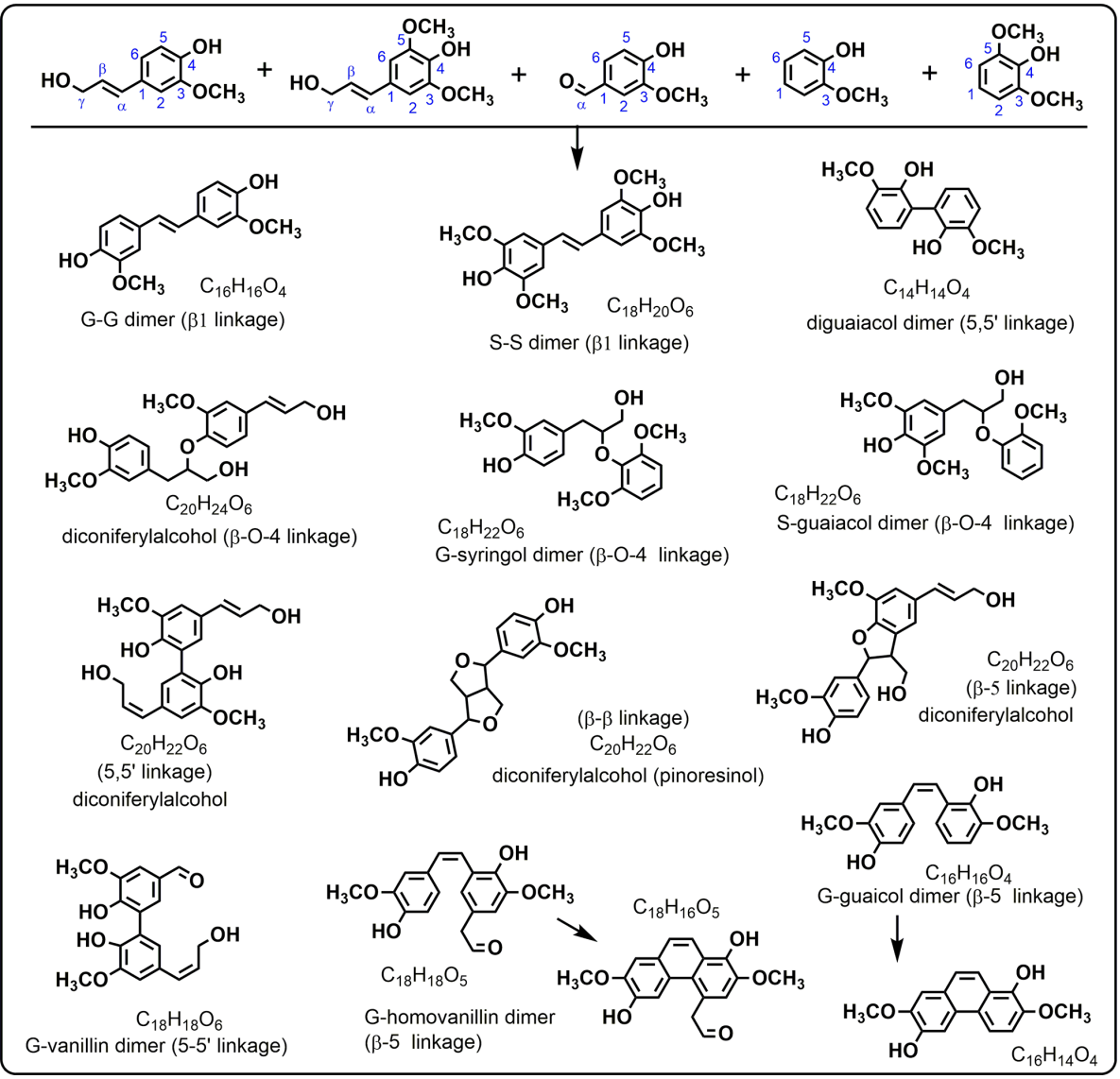

Figure 4. Proposed chemical structures of some monomers and dimers observed in this work. More than one structure may be present at each molecular formula.

5,5'-diguaiacol based on its $\mathrm{C}_{7} \mathrm{H}_{8} \mathrm{O}_{2}$ guaiacol neutral loss fragment, but concurrent losses of $\mathrm{CO}$ and $\mathrm{C}_{2}-\mathrm{C}_{3}$ fragments indicate the presence of other species with the same elemental makeup. Many of the proposed dimer assignments can be rationalized with linkages that are already present in the wood itself (e.g., $\beta$-O-4, $\beta-\beta, \beta-5,5-5^{\prime}$; Watts et al., 2011), suggesting that simple depolymerization of the lignin plays an important role in forming aerosol-phase species, similarly to pyrolysis. Attempts to perform $\mathrm{MS}^{n}$ on most highmolecular-weight peaks were inconclusive due to the higher density of accurate-mass peaks at each $\mathrm{m} / \mathrm{z}$ that provided a challenge for their isolation by the ion trap. Chemical as- 
signments without associated $\mathrm{MS}^{n}$ study in this work should be treated as purely speculative. A representative $\mathrm{MS}^{2}$ spectrum and proposed fragmentation loss pathways are shown in Fig. S7. The full list of common ions, regardless of signal or correlations, is shown in Table S2.

We then performed linear least-squares correlations of the accurate-mass $m / z$ peaks with the aerosol properties of cell toxicity, AhR activity, and visible light absorption $\left(\mathrm{MAC}_{\mathrm{vis}}\right)$ for each WSA sample. A potential concern is that HRMS signals in complex mixtures can suffer from matrix effects so that the signal is not necessarily representative of concentration; however, we found the HRMS signals are strongly correlated with quantitative GC-MS signals (e.g., sinapaldehyde $[\mathrm{M}+\mathrm{H}]^{+} m / z=209.081$, GC retention time $16.6 \mathrm{~min}$, adj. $R^{2}=0.81$; Fig. S8), suggesting that the matrix is similar enough between the different samples that correlations using HRMS are likely meaningful. Peaks are required to be present in eight out of nine samples for the statistical analysis. Table 2 shows the correlation results, the $m / z$ and neutral molecular formulas, neutral or radical loss fragments derived from CID, and proposed assignments for select peaks based on the $\mathrm{MS}^{2}$ evidence when available, the literature previously cited in this article, and guidance from GC-MS observations (Table S1); $90 \%$ of the correlations shown in Table 2 have $p$ values ranging from 0.0002 to 0.05 , while $100 \%$ have $p<0.1$. This suggests that the correlations have moderate to strong evidence against coincidence.

The occurrence of structural isomers is a limitation that may confound the statistics in this work, especially if those isomeric compounds have opposing effects on bioactivity or light absorption. With those caveats in mind, we observed a number of moderate to strong correlations with exact $\mathrm{m} / \mathrm{z}$ peaks, either with a positive or negative effect, for the three aerosol properties examined. A positive effect means that the signal of the peak directly correlates (a higher signal signifies lower cell toxicity $\mathrm{EC}_{50}$, higher AhR activity, and higher $M A C_{v i s}$ ), and a negative effect means anticorrelation, neither of which is necessarily causative. For example, levoglucosan was found to be anticorrelated with $\mathrm{MAC}_{\text {vis }}$ (Fig. 5, $R^{2}=0.75$ ), and we interpret this to mean that lignin derivatives are more likely responsible for visible light absorption because of their highly conjugated structures versus cellulose derivatives (Fig. 4), so when a wood has more cellulose content (producing more levoglucosan), the $\mathrm{MAC}_{\text {vis }}$ decreases. Also, for example, we found the $m / z$ of vanillin to be somewhat correlated with AhR activity $\left(R^{2}=0.45\right)$, and even though vanillin itself is not AhR-active, Bartoňková and Dvořák (2018) found that the complex mixture of vanilla is highly AhR-active, postulating that the AhR activity of the vanilla mixture is caused by minor constituent(s) $(<10 \%)$. Similarly, our correlation of vanillin with AhR activity may be due to vanillin's interaction or co-formation with other constituents in the WSA extract.

The cell toxicity correlations appear to be mainly driven by $\mathrm{C}_{11}$ compounds, some of which are syringyl derivatives.
We found a positive effect of sinapaldehyde and sinapyl alcohol on cell toxicity and possibly for related compounds such as $\mathrm{C}_{11} \mathrm{H}_{14} \mathrm{O}_{5}$ that is tentatively assigned to be sinapyl hydroperoxide. The hydroperoxide assignment is based on the facile $\mathrm{H}_{2} \mathrm{O}$ loss (MacMillan and Murphy, 1995) with lack of $\mathrm{HCOOH}$ and a feasible mechanism of formation, e.g., C-O cleavage of sinapyl alcohol in a heated oxidative environment to form the $\mathrm{R}$ radical (Beste, 2014), that can add $\mathrm{O}_{2}$ and then form the $\mathrm{ROOH}$ through reaction with $\mathrm{HO}_{2}$ or other RH (Atkinson, 2000). This is somewhat consistent with sinapaldehyde's strong effect on inhibiting the growth of bacterial cells, while other phenolic compounds like vanillin and syringaldehyde had no effect (Figueiredo et al., 2008). Similarly, syringaldehyde and vanillin had no effect in our cell toxicity assay. The potential toxicity of monolignols like sinapyl alcohol has been noted in plants (Whetten and Sederoff, 1995), and while we would expect that coniferyl alcohol may have a similar effect, no correlation was observed. Among other factors, this could be due to isomeric compounds present at the coniferyl alcohol $\mathrm{m} / \mathrm{z}$, including an acid ( $\mathrm{HCOOH}$ loss) and aldehyde (CO loss), compared to the sinapyl alcohol peak that did not have these interferences. Another positively correlated molecular formula is $\mathrm{C}_{14} \mathrm{H}_{16} \mathrm{O}_{2}\left(R^{2}=0.74\right)$ that appears to belong to compounds with quinone, furfuryl alcohol, and other substructures in the WSA based on fragmentation patterns, so it is not clear which compounds specifically affect cell toxicity. Quinones can be cytotoxic or cytoprotective depending on structure (Bolton and Dunlap, 2016), and furfuryl alcohol can be mildly immunotoxic (Franko et al., 2011); therefore, the correlation has mechanistic plausibility. We found that 5-hydroxymethylfurfural (HMF), an important decomposition product of cellulose, was anticorrelated with cell toxicity $\left(R^{2}=0.54\right)$ for reasons that are unclear. HMF can be biologically active; however, this occurs at a dose that would be unfeasibly high for human exposure ( $\sim 200 \mathrm{~g}$ based on the oral acute $\mathrm{LD}_{50}$ of $2.5-3.1 \mathrm{~g} \mathrm{~kg}^{-1}$ in rats; Hoydonckx et al., 2000) and we would expect it to have no effect on cell toxicity in our assay. It is possible that HMF is anticorrelated because of its connection with levoglucosan, which is also anticorrelated but with a weaker relationship $\left(R^{2}=0.31\right)$ and consequently not included in Table 2. If so, the interpretation would be similar to that for $\mathrm{MAC}_{\mathrm{vis}}$; i.e., a higher lignin / cellulose ratio in the wood may increase cell toxicity in the smoldering WSA.

In this study, compounds that correlate with AhR activity tend to have more carbons than the lignin monomers (mainly $\mathrm{C}_{14}-\mathrm{C}_{19}$ ) and more $\mathrm{C}=\mathrm{C}$ unsaturation. These compounds are either formed in the combustion or exist naturally in wood, as wood dust itself has been shown to be AhR-active (Wilson et al., 2015). The calculated double-bond equivalents (rings $+\pi$-bonds $=$ DBE; Badertscher et al., 2001) are consistent with AhR-active compounds having more unsaturation on average. Average DBEs for the positively correlated compounds $(<\mathrm{DBE}>=8.0, \max 11)$ are notably 
Table 2. Peaks observed in at least eight out of nine samples with either correlations with aerosol properties or other significance (e.g., high signals). The average normalized signal-to-noise ratios in all samples and the neutral molecular formulas are shown. Entries have $p$ values $\leq 0.05(90 \%)$, or $p<0.1(100 \%)$.

\begin{tabular}{|c|c|c|c|c|c|c|c|c|c|c|c|c|c|}
\hline \multirow{2}{*}{$\begin{array}{l}\text { Obs. } \\
m / z\end{array}$} & \multirow{2}{*}{$\begin{array}{l}S / N \\
(\%)\end{array}$} & \multicolumn{4}{|c|}{ Formula } & \multicolumn{2}{|c|}{ Tox } & \multicolumn{2}{|c|}{ AhR } & \multicolumn{2}{|c|}{ MAC } & \multirow{2}{*}{$\begin{array}{l}\text { Proposed chemical } \\
\text { assignment(s) }\end{array}$} & \multirow{2}{*}{$\begin{array}{l}\text { CID neutral or } \\
\text { radical losses }\end{array}$} \\
\hline & & $\mathrm{C}$ & $\mathrm{H}$ & $\mathrm{O}$ & $\mathrm{N}$ & Sign & $R^{2}$ & Sign & $R^{2}$ & Sign & $R^{2}$ & & \\
\hline 127.039 & 1.3 & 6 & 6 & 3 & 0 & neg & 0.54 & pos & 0.40 & - & - & 5-hydroxymethyl furfural & $\begin{array}{l}\mathrm{H}_{2} \mathrm{O}, \mathrm{CO}, \mathrm{C}_{2} \mathrm{H}_{2} \mathrm{O}_{2} \\
\left(\mathrm{CH}_{2} \mathrm{O}+\mathrm{CO} ?\right)\end{array}$ \\
\hline 129.054 & 0.3 & 6 & 8 & 3 & 0 & neg & 0.58 & - & - & - & - & - & - \\
\hline 137.059 & 1.3 & 8 & 8 & 2 & 0 & - & - & - & - & - & - & toluic acid, anisaldehyde & $\begin{array}{l}\mathrm{CH}_{3}, \mathrm{H}_{2} \mathrm{O}, \mathrm{CO}, \mathrm{HCOOH} \\
\mathrm{CH}_{2} \mathrm{O}+\mathrm{CO}\end{array}$ \\
\hline 139.075 & 0.2 & 8 & 10 & 2 & 0 & - & - & - & - & - & - & methylguaiacol & \\
\hline 141.054 & 0.3 & 7 & 8 & 3 & 0 & - & - & - & - & pos & 0.52 & $\begin{array}{l}\text { methoxymethyl-furfural, } \\
\text { others }\end{array}$ & $\mathrm{CO}, \mathrm{CH}_{4} \mathrm{O}, \mathrm{CH}_{2} \mathrm{O}+\mathrm{CO}$ \\
\hline 143.034 & 0.8 & 6 & 6 & 4 & 0 & - & - & - & - & - & - & $\begin{array}{l}\text { 5-hydroxymethyl-2- } \\
\text { furancarboxylic acid }\end{array}$ & $\mathrm{HCOOH}, \mathrm{H}_{2} \mathrm{O}$ \\
\hline 143.070 & 0.2 & 7 & 10 & 3 & 0 & - & - & - & - & pos & 0.46 & $\begin{array}{l}\text { methoxyfuranethanol, } \\
\text { hydroxymethylfuranethanol }\end{array}$ & $\mathrm{CH}_{3} \mathrm{OH}, \mathrm{H}_{2} \mathrm{O}$ \\
\hline 149.059 & 0.2 & 9 & 8 & 2 & 0 & - & - & - & - & - & - & coumaraldehyde & - \\
\hline 151.039 & 0.6 & 8 & 6 & 3 & 0 & neg & 0.46 & pos & 0.44 & neg & 0.47 & hydroxyphenylglyoxal & $\mathrm{C}_{2} \mathrm{H}_{2} \mathrm{O}, \mathrm{CO}, \mathrm{H}_{2} \mathrm{O}$ \\
\hline 151.075 & 0.7 & 9 & 10 & 2 & 0 & - & - & - & - & - & - & $\begin{array}{l}\text { methoxyvinylphenol, } \\
\text { coumaryl alcohol }\end{array}$ & $\begin{array}{l}\mathrm{CO}, \mathrm{CH}_{3} \mathrm{OH}, \mathrm{H}_{2} \mathrm{O}, \mathrm{C}_{3} \mathrm{H}_{6}, \\
\mathrm{C}_{3} \mathrm{H}_{4} \mathrm{O}, \mathrm{C}_{2} \mathrm{H}_{4} \mathrm{O}_{2}\end{array}$ \\
\hline 153.054 & 0.8 & 8 & 8 & 3 & 0 & neg & 0.47 & pos & 0.45 & - & - & $\begin{array}{l}\text { vanillin (minor } \\
\text { methoxybenzoic acid) }\end{array}$ & $\begin{array}{l}\mathrm{CO}, \mathrm{CH}_{3} \mathrm{OH}(\text { minor } \\
\left.\mathrm{HCOOH}, \mathrm{CH}_{3} \mathrm{OH}+\mathrm{CO}_{2}\right)\end{array}$ \\
\hline 153.091 & 0.2 & 9 & 12 & 2 & 0 & - & - & - & - & pos & 0.59 & hydroxypropylphenol & $\mathrm{H}_{2} \mathrm{O}, \mathrm{C}_{3} \mathrm{H}_{8} \mathrm{O}$ \\
\hline 155.070 & 0.6 & 8 & 10 & 3 & 0 & - & - & - & - & - & - & $\begin{array}{l}\text { syringol, hydroxyl- } \\
\text { ethylbenzene diol }\end{array}$ & $\begin{array}{l}\mathrm{CH}_{3} \mathrm{OH}, \mathrm{CH}_{3}, \mathrm{H}_{2} \mathrm{O} \\
\mathrm{C}_{2} \mathrm{H}_{4} \mathrm{O}_{2}\end{array}$ \\
\hline 163.039 & 0.7 & 9 & 6 & 3 & 0 & - & - & - & - & - & - & hydroxycoumarin & $\mathrm{CO}, \mathrm{CO}_{2}$ \\
\hline 163.075 & 0.7 & 10 & 10 & 2 & 0 & neg & 0.43 & pos & 0.72 & - & - & methoxy-cinnamaldehyde & $\begin{array}{l}\mathrm{CO}, \mathrm{CH}_{3} \mathrm{OH}, \mathrm{C}_{2} \mathrm{H}_{2} \mathrm{O} \\
\mathrm{C}_{3} \mathrm{H}_{4} \mathrm{O}\end{array}$ \\
\hline 165.091 & 0.4 & 10 & 12 & 2 & 0 & - & - & - & - & - & - & eugenol, isoeugenol & $\mathrm{H}_{2} \mathrm{O}, \mathrm{CH}_{3} \mathrm{OH}, \mathrm{C}_{3} \mathrm{H}_{6}$ \\
\hline 167.070 & 2.7 & 9 & 10 & 3 & 0 & - & - & neg & 0.44 & - & - & $\begin{array}{l}\text { homovanillin, } \\
\text { acetovanillone }\end{array}$ & $\begin{array}{l}\mathrm{CH}_{3}, \mathrm{H}_{2} \mathrm{O}, \mathrm{CO}, \mathrm{CH}_{3} \mathrm{OH} \\
\mathrm{C}_{2} \mathrm{H}_{2} \mathrm{O}, \mathrm{CH}_{2} \mathrm{O}_{2}, \mathrm{C}_{2} \mathrm{H}_{4} \mathrm{O}_{2}\end{array}$ \\
\hline 169.049 & 0.4 & 8 & 8 & 4 & 0 & - & - & - & - & - & - & $\begin{array}{l}\text { vanillic acid, } \\
\text { dihydroxyphenylacetic acid }\end{array}$ & $\begin{array}{l}\mathrm{CO}, \mathrm{H}_{2} \mathrm{O}, \mathrm{CH}_{3}, \mathrm{HCOOH} \\
\mathrm{C}_{2} \mathrm{H}_{2} \mathrm{O}, \mathrm{C}_{2} \mathrm{H}_{4} \mathrm{O}_{2}\end{array}$ \\
\hline 169.086 & 0.6 & 9 & 12 & 3 & 0 & - & - & - & - & pos & 0.46 & homovanillyl alcohol & $\mathrm{C}_{2} \mathrm{H}_{4} \mathrm{O}, \mathrm{H}_{2} \mathrm{O}, \mathrm{CH}_{3} \mathrm{OH}$ \\
\hline 177.054 & 1.2 & 10 & 8 & 3 & 0 & - & - & - & - & - & - & $\begin{array}{l}\text { methoxycoumarin, } \\
\text { hydroxymethyl-coumarin }\end{array}$ & $\mathrm{CO}, \mathrm{CH}_{3} \mathrm{OH}, \mathrm{C}_{4} \mathrm{H}_{4} \mathrm{O}, \mathrm{CH}_{3}$ \\
\hline 177.091 & 0.3 & 11 & 12 & 2 & 0 & - & - & - & - & pos & 0.59 & ethylcinnamate & $\mathrm{H}_{2} \mathrm{O}, \mathrm{C}_{2} \mathrm{H}_{4}, \mathrm{C}_{2} \mathrm{H}_{2} \mathrm{O}$ \\
\hline 179.070 & 3.0 & 10 & 10 & 3 & 0 & - & - & - & - & - & - & $\begin{array}{l}\text { coniferaldehyde, } \\
\text { methoxycinammic acid }\end{array}$ & $\begin{array}{l}\mathrm{H}_{2} \mathrm{O}, \mathrm{CO}, \mathrm{CH}_{3} \mathrm{OH}, \\
\mathrm{HCOOH}, \mathrm{C}_{2} \mathrm{H}_{2} \mathrm{O}, \mathrm{C}_{3} \mathrm{H}_{4} \mathrm{O}\end{array}$ \\
\hline 179.106 & 0.1 & 11 & 14 & 2 & 0 & - & - & - & - & pos & 0.77 & - & $\begin{array}{l}\mathrm{CO}, \mathrm{C}_{2} \mathrm{H}_{4} \mathrm{O}, \mathrm{C}_{2} \mathrm{H}_{4} \mathrm{O}_{2} \\
\left(\mathrm{CO}+\mathrm{CH}_{3} \mathrm{OH} ?\right)\end{array}$ \\
\hline 181.086 & 1.3 & 10 & 12 & 3 & 0 & - & - & - & - & pos & 0.51 & $\begin{array}{l}\text { coniferyl alcohol, } \\
\text { dihydroconiferald-ehyde, } \\
\text { methoxyphenyl-propanoic } \\
\text { acid }\end{array}$ & $\begin{array}{l}\mathrm{H}_{2} \mathrm{O}, \mathrm{CH}_{3}, \mathrm{CO}, \mathrm{C}_{2} \mathrm{H}_{4}, \\
\mathrm{C}_{2} \mathrm{H}_{2} \mathrm{O}, \mathrm{C}_{3} \mathrm{H}_{6}, \mathrm{HCOOH}, \\
\mathrm{C}_{2} \mathrm{H}_{6} \mathrm{O}, \mathrm{C}_{3} \mathrm{H}_{4} \mathrm{O}, \mathrm{C}_{2} \mathrm{H}_{4} \mathrm{O}_{2}, \\
\mathrm{C}_{3} \mathrm{H}_{6} \mathrm{O}_{2}\end{array}$ \\
\hline 183.065 & 1.8 & 9 & 10 & 4 & 0 & - & - & - & - & - & - & $\begin{array}{l}\text { syringaldehyde, } \\
\text { homovanillic acid }\end{array}$ & $\begin{array}{l}\mathrm{H}_{2} \mathrm{O}, \mathrm{CO}, \mathrm{HCOOH} \\
\mathrm{CH}_{3} \mathrm{OH}, \mathrm{C}_{2} \mathrm{H}_{4} \mathrm{O}_{2}\end{array}$ \\
\hline 183.101 & 0.4 & 10 & 14 & 3 & 0 & - & - & - & - & pos & 0.76 & $\begin{array}{l}\text { dihydroconiferyl alcohol, } \\
\text { others }\end{array}$ & - \\
\hline
\end{tabular}


Table 2. Continued.

\begin{tabular}{|c|c|c|c|c|c|c|c|c|c|c|c|c|c|}
\hline \multirow{2}{*}{$\begin{array}{l}\text { Obs. } \\
m / z\end{array}$} & \multirow{2}{*}{$\begin{array}{r}S / N \\
(\%)\end{array}$} & \multicolumn{4}{|c|}{ Formula } & \multicolumn{2}{|c|}{ Tox } & \multicolumn{2}{|c|}{ AhR } & \multicolumn{2}{|c|}{ MAC } & \multirow{2}{*}{$\begin{array}{l}\text { Proposed chemical } \\
\text { assignment(s) }\end{array}$} & \multirow{2}{*}{$\begin{array}{l}\text { CID neutral or } \\
\text { radical losses }\end{array}$} \\
\hline & & $\mathrm{C}$ & $\mathrm{H}$ & $\mathrm{O}$ & $\mathrm{N}$ & Sign & $R^{2}$ & Sign & $R^{2}$ & Sign & $R^{2}$ & & \\
\hline 185.042 & 1.2 & 6 & 10 & 5 & 0 & - & - & - & - & neg & 0.75 & $\begin{array}{l}\text { levoglucosan, mannosan, } \\
\text { galactosan }\end{array}$ & $\mathrm{H}_{2} \mathrm{O}$ \\
\hline 187.075 & 0.2 & 12 & 10 & 2 & 0 & - & - & - & - & pos & 0.47 & phenyl furancarbaldehyde & $\mathrm{CO}, \mathrm{C}_{5} \mathrm{H}_{5} \mathrm{O}_{2}$ \\
\hline 191.070 & 1.2 & 11 & 10 & 3 & 0 & - & - & - & - & pos & 0.64 & acetyl coumaraldehyde & $\mathrm{CO}, \mathrm{H}_{2} \mathrm{O}, \mathrm{CH}_{3}, \mathrm{C}_{2} \mathrm{H}_{4} \mathrm{O}_{2}$ \\
\hline 191.106 & 0.2 & 12 & 14 & 2 & 0 & - & - & - & - & pos & 0.49 & isoeugenyl acetone & - \\
\hline 193.049 & 0.6 & 10 & 8 & 4 & 0 & - & - & - & - & neg & 0.47 & $\begin{array}{l}\text { hydroxy(oxopropenyl)benzoic } \\
\text { acid }\end{array}$ & $\mathrm{CH}_{3}, \mathrm{CO}, \mathrm{H}_{2} \mathrm{O}, \mathrm{HCOOH}$ \\
\hline 193.086 & 1.4 & 11 & 12 & 3 & 0 & - & - & - & - & pos & 0.78 & $\begin{array}{l}\text { vanillylidene acetone, } \\
\text { dimethoxyphenylacrylalde- } \\
\text { hyde }\end{array}$ & $\begin{array}{l}\mathrm{CH}_{3} \mathrm{OH}, \mathrm{H}_{2} \mathrm{O}, \mathrm{CO}, \\
\mathrm{C}_{2} \mathrm{H}_{2} \mathrm{O}_{2}, \mathrm{C}_{3} \mathrm{H}_{4} \mathrm{O}, \mathrm{C}_{2} \mathrm{H}_{4} \mathrm{O}_{2}, \\
\mathrm{C}_{2} \mathrm{H}_{4} \mathrm{O}, \mathrm{C}_{3} \mathrm{H}_{4} \mathrm{O}_{3}\end{array}$ \\
\hline 195.101 & 0.7 & 11 & 14 & 3 & 0 & pos & 0.55 & neg & 0.41 & pos & 0.57 & $\begin{array}{l}\text { methoxyisoeugenol, } \\
\text { vanillylacetone }\end{array}$ & - \\
\hline 197.080 & 1.7 & 10 & 12 & 4 & 0 & - & - & - & - & - & - & acetosyringone & $\begin{array}{l}\mathrm{C}_{2} \mathrm{H}_{2} \mathrm{O}, \mathrm{H}_{2} \mathrm{O}, \mathrm{CH}_{3} \mathrm{OH} \\
\mathrm{C}_{2} \mathrm{H}_{2} \mathrm{O}+\mathrm{H}_{2} \mathrm{O}\end{array}$ \\
\hline 197.117 & 0.1 & 11 & 16 & 3 & 0 & - & - & - & - & pos & 0.80 & - & - \\
\hline 198.076 & 0.7 & 9 & 11 & 4 & 1 & - & - & - & - & - & - & pyridine derivative & $\mathrm{C}_{4} \mathrm{H}_{6} \mathrm{O}_{3}, \mathrm{H}_{2} \mathrm{O}, \mathrm{C}_{5} \mathrm{H}_{5} \mathrm{NO}$ \\
\hline 199.060 & 0.2 & 9 & 10 & 5 & 0 & - & - & - & - & - & - & syringic acid & - \\
\hline 201.091 & 0.2 & 13 & 12 & 2 & 0 & - & - & - & - & pos & 0.63 & - & - \\
\hline 205.084 & 1.1 & 10 & 14 & 3 & 0 & - & - & - & - & - & - & $\begin{array}{l}\text { dihydroconiferyl alcohol, } \\
\text { unknown aldehyde }\end{array}$ & $\begin{array}{l}\mathrm{CH}_{3}, \mathrm{H}_{2} \mathrm{O}, \mathrm{CO}, \mathrm{CH}_{3} \mathrm{OH}, \\
\mathrm{C}_{2} \mathrm{H}_{2} \mathrm{O}, \mathrm{HCOOH}, \mathrm{C}_{3} \mathrm{H}_{4} \mathrm{O}, \\
\mathrm{C}_{2} \mathrm{H}_{2} \mathrm{O}_{2}\end{array}$ \\
\hline 207.065 & 0.7 & 11 & 10 & 4 & 0 & - & - & - & - & - & - & - & $\mathrm{H}_{2} \mathrm{O}$ \\
\hline 207.101 & 0.6 & 12 & 14 & 3 & 0 & - & - & - & - & pos & 0.70 & acetyleugenol & $\mathrm{CH}_{3} \mathrm{OH}, \mathrm{C}_{2} \mathrm{H}_{4} \mathrm{O}_{2}$ \\
\hline 209.080 & 5.8 & 11 & 12 & 4 & 0 & pos & 0.49 & neg & 0.51 & - & - & $\begin{array}{l}\text { sinapaldehyde (minor } \\
\text { dimethoxycinammic acid) }\end{array}$ & $\begin{array}{l}\mathrm{H}_{2} \mathrm{O}, \mathrm{CO}, \mathrm{CH}_{3}, \mathrm{CH}_{3} \mathrm{OH} \\
\mathrm{C}_{2} \mathrm{H}_{2} \mathrm{O}, \mathrm{C}_{3} \mathrm{H}_{4} \mathrm{O}, \mathrm{HCOOH} \\
\mathrm{CH}_{2} \mathrm{O}+\mathrm{CH}_{2} \mathrm{O}\end{array}$ \\
\hline 209.117 & 0.1 & 12 & 16 & 3 & 0 & - & - & - & - & pos & 0.88 & & - \\
\hline 211.096 & 3.7 & 11 & 14 & 4 & 0 & pos & 0.44 & neg & 0.56 & - & - & sinapyl alcohol & $\begin{array}{l}\mathrm{H}_{2} \mathrm{O}, \mathrm{CH}_{3} \mathrm{OH}, \\
\mathrm{CH}_{2} \mathrm{O}+\mathrm{CH}_{2} \mathrm{O}, \mathrm{C}_{3} \mathrm{H}_{6} \mathrm{O}_{2} \\
\left(\text { maybe } \mathrm{C}_{3} \mathrm{H}_{4} \mathrm{O}+\mathrm{H}_{2} \mathrm{O}\right)\end{array}$ \\
\hline 219.101 & 0.8 & 13 & 14 & 3 & 0 & - & - & pos & 0.41 & - & - & $\begin{array}{l}\text { unknown phenols, } \\
\text { G-methylfuran }(\alpha-2) \text { dimer }\end{array}$ & $\begin{array}{l}\mathrm{CH}_{3}, \mathrm{H}_{2} \mathrm{O}, \mathrm{CO}, \mathrm{CH}_{3} \mathrm{OH}, \\
\mathrm{C}_{2} \mathrm{H}_{2} \mathrm{O}, \mathrm{HCOOH}, \mathrm{C}_{3} \mathrm{H}_{4} \mathrm{O}, \\
\mathrm{C}_{2} \mathrm{H}_{2} \mathrm{O}_{2}, \mathrm{C}_{3} \mathrm{H}_{6} \mathrm{O}_{2}, \mathrm{C}_{5} \mathrm{H}_{6} \mathrm{O}, \\
\mathrm{C}_{3} \mathrm{H}_{4} \mathrm{O}_{3}, \mathrm{C}_{7} \mathrm{H}_{8} \mathrm{O}_{2}\end{array}$ \\
\hline 221.080 & 0.5 & 12 & 12 & 4 & 0 & - & - & - & - & - & - & acetoconiferaldehyde & $\begin{array}{l}\mathrm{CH}_{3}, \mathrm{H}_{2} \mathrm{O}, \mathrm{CO}, \mathrm{CH}_{3} \mathrm{OH}, \\
\mathrm{C}_{2} \mathrm{H}_{2} \mathrm{O}, \mathrm{HCOOH}, \mathrm{C}_{2} \mathrm{H}_{4} \mathrm{O}_{2}\end{array}$ \\
\hline 221.117 & 0.2 & 13 & 16 & 3 & 0 & - & - & - & - & pos & 0.94 & $\begin{array}{l}\text { eugenyl propionate, and } \\
\text { another phenol }\end{array}$ & $\begin{array}{l}\mathrm{H}_{2} \mathrm{O}, \mathrm{CO}, \mathrm{CH}_{3} \mathrm{OH}, \mathrm{C}_{3} \mathrm{H}_{6}, \\
\mathrm{C}_{3} \mathrm{H}_{6} \mathrm{O}_{2}\end{array}$ \\
\hline 223.060 & 0.4 & 11 & 10 & 5 & 0 & pos & 0.49 & neg & 0.62 & - & - & - & - \\
\hline 223.096 & 0.6 & 12 & 14 & 4 & 0 & pos & 0.54 & neg & 0.53 & - & - & tetrahydrofuran derivative & $\mathrm{C}_{4} \mathrm{H}_{8} \mathrm{O}, \mathrm{C}_{5} \mathrm{H}_{10} \mathrm{O}$ \\
\hline 225.111 & 0.2 & 12 & 16 & 4 & 0 & pos & 0.57 & - & - & pos & 0.60 & - & - \\
\hline 227.052 & 1.2 & 5 & 10 & 8 & 2 & neg & 0.43 & pos & 0.50 & neg & 0.58 & $\begin{array}{l}\text { unknown nitro or nitrate } \\
\text { derivative }\end{array}$ & $\mathrm{H}_{2} \mathrm{O}, \mathrm{CH}_{3} \mathrm{OH}, \mathrm{CH}_{5} \mathrm{NO}_{2}$ \\
\hline 227.091 & 0.3 & 11 & 14 & 5 & 0 & pos & 0.69 & neg & 0.66 & - & - & sinapyl hydroperoxide & $\mathrm{H}_{2} \mathrm{O}$ \\
\hline 229.084 & 0.2 & 14 & 12 & 3 & 0 & - & - & pos & 0.57 & - & - & resveratrol & $\mathrm{H}_{2} \mathrm{O}$ \\
\hline
\end{tabular}


Table 2. Continued.

\begin{tabular}{|c|c|c|c|c|c|c|c|c|c|c|c|c|c|}
\hline \multirow{2}{*}{$\begin{array}{l}\text { Obs. } \\
m / z\end{array}$} & \multirow{2}{*}{$\begin{array}{r}S / N \\
(\%)\end{array}$} & \multicolumn{4}{|c|}{ Formula } & \multicolumn{2}{|c|}{ Tox } & \multicolumn{2}{|c|}{ AhR } & \multicolumn{2}{|c|}{ MAC } & \multirow{2}{*}{$\begin{array}{l}\text { Proposed chemical } \\
\text { assignment(s) }\end{array}$} & \multirow{2}{*}{$\begin{array}{l}\text { CID neutral or } \\
\text { radical losses }\end{array}$} \\
\hline & & $\mathrm{C}$ & $\mathrm{H}$ & $\mathrm{O}$ & $\mathrm{N}$ & Sign & $R^{2}$ & Sign & $R^{2}$ & Sign & $R^{2}$ & & \\
\hline 235.096 & 0.6 & 13 & 14 & 4 & 0 & - & - & - & - & pos & 0.56 & - & - \\
\hline 237.111 & 0.3 & 13 & 16 & 4 & 0 & pos & 0.52 & neg & 0.44 & pos & 0.53 & - & - \\
\hline 239.091 & 0.1 & 12 & 14 & 5 & 0 & pos & 0.52 & neg & 0.48 & - & - & - & - \\
\hline 245.080 & 0.2 & 14 & 12 & 4 & 0 & neg & 0.50 & pos & 0.57 & - & - & - & - \\
\hline 247.096 & 0.5 & 14 & 14 & 4 & 0 & - & - & - & - & - & - & diguaiacol $\left(5,5^{\prime}\right)$, others & $\begin{array}{l}\mathrm{H}_{2} \mathrm{O}, \mathrm{CH}_{3}, \mathrm{CH}_{3} \mathrm{OH}, \mathrm{CO}, \\
\mathrm{C}_{2} \mathrm{H}_{4} \mathrm{O}_{2}, \mathrm{C}_{2} \mathrm{H}_{2} \mathrm{O}, \mathrm{HCOOH}, \\
\mathrm{C}_{3} \mathrm{H}_{4} \mathrm{O}_{3}, \mathrm{C}_{3} \mathrm{H}_{4} \mathrm{O}, \mathrm{C}_{3} \mathrm{H}_{6} \mathrm{O}_{2}, \\
\mathrm{C}_{6} \mathrm{H}_{6} \mathrm{O}_{2}, \mathrm{C}_{7} \mathrm{H}_{8} \mathrm{O}_{2}\end{array}$ \\
\hline 247.132 & 0.2 & 15 & 18 & 3 & 0 & - & - & - & - & pos & 0.41 & - & - \\
\hline 249.111 & 0.7 & 14 & 16 & 4 & 0 & pos & 0.74 & neg & 0.60 & pos & 0.49 & $\begin{array}{l}\text { furfuryl alcohol deriv., } \\
\text { hydroxybenzoquinone } \\
\text { derivative }\left(\mathrm{C}_{6} \mathrm{H}_{4} \mathrm{O}_{3}^{+}\right. \\
\text {fragment ion), others }\end{array}$ & $\begin{array}{l}\mathrm{H}_{2} \mathrm{O}, \mathrm{C}_{8} \mathrm{H}_{12} \mathrm{O}, \mathrm{CO}, \\
\mathrm{CH}_{3} \mathrm{OH}, \mathrm{C}_{6} \mathrm{H}_{8} \mathrm{O}_{2}, \\
\mathrm{C}_{3} \mathrm{H}_{6} \mathrm{O}_{2}, \mathrm{C}_{2} \mathrm{H}_{4} \mathrm{O}_{2}, \\
\mathrm{C}_{4} \mathrm{H}_{6} \mathrm{O}_{3}, \mathrm{C}_{4} \mathrm{H}_{6} \mathrm{O}_{3}, \\
\mathrm{C}_{5} \mathrm{H}_{6} \mathrm{O}_{2}, \mathrm{C}_{4} \mathrm{H}_{8} \mathrm{O}_{2}, \mathrm{C}_{3} \mathrm{H}_{6}\end{array}$ \\
\hline 251.127 & 0.1 & 14 & 18 & 4 & 0 & - & - & - & - & pos & 0.64 & - & - \\
\hline 261.112 & 0.5 & 15 & 16 & 4 & 0 & - & - & - & - & - & - & $\begin{array}{l}\text { G-guaiacol dimer }(\alpha-2) \text {, } \\
\text { others }\end{array}$ & - \\
\hline 265.106 & 0.3 & 14 & 16 & 5 & 0 & - & - & - & - & pos & 0.46 & $\begin{array}{l}\text { S-furfurylalcohol dimer } \\
(\alpha-2)\end{array}$ & - \\
\hline 271.096 & 0.3 & 16 & 14 & 4 & 0 & neg & 0.63 & pos & 0.65 & - & - & $\begin{array}{l}\text { G-guaicol ( } \beta-5 \text {, ring } \\
\text { closure) }\end{array}$ & - \\
\hline 273.112 & 0.2 & 16 & 16 & 4 & 0 & - & - & - & - & - & - & $\begin{array}{l}\text { diguaicol }(\beta-1), \text { G-guaicol } \\
(\beta-5)\end{array}$ & \\
\hline 289.106 & 0.6 & 16 & 16 & 5 & 0 & - & - & - & - & - & - & $\begin{array}{l}\text { G-syringol dimer }(\beta-5) \text {, } \\
\text { others }\end{array}$ & - \\
\hline 301.107 & 0.3 & 17 & 16 & 5 & 0 & neg & 0.41 & pos & 0.55 & - & - & G-vanillin dimer $(\beta-5)$ & - \\
\hline 303.122 & 0.3 & 17 & 18 & 5 & 0 & neg & 0.44 & pos & 0.58 & - & - & $\begin{array}{l}\text { guaicyl-syringyl dimer } \\
\text { (stilbene), others }\end{array}$ & - \\
\hline 305.138 & 0.3 & 17 & 20 & 5 & 0 & - & - & - & - & pos & 0.67 & G-guaiacol dimer $(\beta-\mathrm{O}-4)$ & - \\
\hline 313.107 & 0.2 & 18 & 16 & 5 & 0 & - & - & pos & 0.40 & - & - & $\begin{array}{l}\text { G-homovanillin dimer }(\beta-5 \text {, } \\
\text { ring closure), others }\end{array}$ & - \\
\hline 315.122 & 0.3 & 18 & 18 & 5 & 0 & - & - & pos & 0.50 & - & - & $\begin{array}{l}\text { G-homovanillin dimer } \\
(\beta-5) \text {, others }\end{array}$ & - \\
\hline 317.138 & 0.2 & 18 & 20 & 5 & 0 & - & - & pos & 0.43 & - & - & G-G dimer $(\alpha-5)$ & - \\
\hline 327.122 & 0.3 & 19 & 18 & 5 & 0 & - & - & - & - & - & - & $\begin{array}{l}\text { G-coniferaldehyde dimer } \\
(\beta-1), \text { others }\end{array}$ & - \\
\hline 329.102 & 0.1 & 18 & 16 & 6 & 0 & - & - & pos & 0.40 & - & - & $\begin{array}{l}\text { S-vanillin dimer }(\beta-5 \\
\text { ring closure), hydroxy } \\
\text { G-homovanillin dimer }(\beta-5 \text {, } \\
\text { ring closure), others }\end{array}$ & - \\
\hline 329.138 & 0.3 & 19 & 20 & 5 & 0 & - & - & pos & 0.42 & - & - & $\begin{array}{l}\text { eugenol-vanillone dimer } \\
\left(5,5^{\prime}\right) \text {, others }\end{array}$ & - \\
\hline 331.117 & 1.0 & 18 & 18 & 6 & 0 & - & - & - & - & pos & 0.44 & $\begin{array}{l}\text { G-vanillin dimer }\left(5,5^{\prime}\right) \text {, } \\
\text { others }\end{array}$ & - \\
\hline 345.132 & 0.2 & 19 & 20 & 6 & 0 & - & - & - & - & pos & 0.60 & $\begin{array}{l}\text { coniferylalcohol-vanillone } \\
\text { dimer }\left(5,5^{\prime}\right) \text {, others }\end{array}$ & - \\
\hline
\end{tabular}


Table 2. Continued.

\begin{tabular}{|c|c|c|c|c|c|c|c|c|c|c|c|c|c|}
\hline \multirow{2}{*}{$\begin{array}{l}\text { Obs. } \\
m / z\end{array}$} & \multirow{2}{*}{$\begin{array}{l}S / N \\
(\%)\end{array}$} & \multicolumn{4}{|c|}{ Formula } & \multicolumn{2}{|c|}{ Tox } & \multicolumn{2}{|c|}{ AhR } & \multicolumn{2}{|c|}{ MAC } & \multirow{2}{*}{$\begin{array}{l}\text { Proposed chemical } \\
\text { assignment(s) }\end{array}$} & \multirow{2}{*}{$\begin{array}{l}\text { CID neutral or } \\
\text { radical losses }\end{array}$} \\
\hline & & $\mathrm{C}$ & $\mathrm{H}$ & $\mathrm{O}$ & $\mathrm{N}$ & Sign & $R^{2}$ & Sign & $R^{2}$ & Sign & $R^{2}$ & & \\
\hline 333.133 & 0.4 & 18 & 20 & 6 & 0 & - & - & - & - & - & - & $\begin{array}{l}\text { S-S dimer }(\beta-1), \mathrm{G} \text {-vanillin } \\
\text { dimer }(\beta-\mathrm{O}-4)\end{array}$ & - \\
\hline 357.130 & 1.3 & 18 & 22 & 6 & 0 & - & - & - & - & - & - & $\begin{array}{l}\text { G-syringol dimer or } \\
\text { S-guaiacol dimer }(\beta-\mathrm{O}-4)\end{array}$ & - \\
\hline 359.148 & 0.2 & 20 & 22 & 6 & 0 & - & - & - & - & pos & 0.77 & $\begin{array}{l}\text { diconiferylalcohol }\left(5,5^{\prime},\right. \\
\beta-\beta, \text { or } \beta-) \text {, and others }\end{array}$ & - \\
\hline 383.146 & 0.2 & 20 & 24 & 6 & 0 & - & - & - & - & - & - & diconiferylalcohol $(\beta-\mathrm{O}-4)$ & - \\
\hline
\end{tabular}
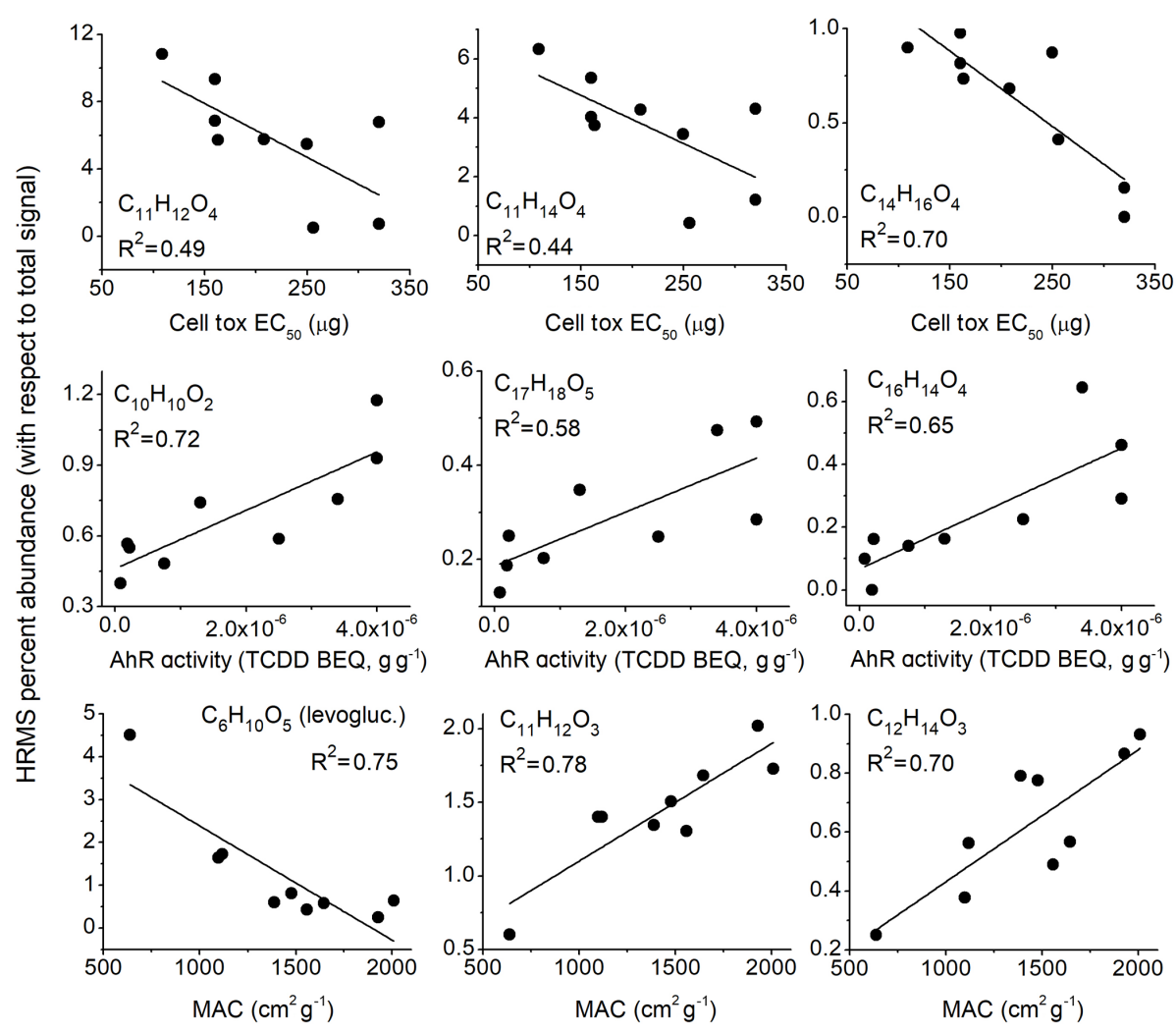

Figure 5. Select correlations of HRMS peaks with cell toxicity $\mathrm{EC}_{50}$, AhR activity, and $\mathrm{MAC}_{\mathrm{vis}}$. Linear fits and correlation coefficients are shown. Proposed chemical identities are listed in Table 1.

higher than those that are not correlated $(<\mathrm{DBE}>=6.2$, $\max 11)$ and those that are anticorrelated $(<\mathrm{DBE}>=5.6$, max 7). This explanation is an oversimplification, as double bonds and even aromaticity do not account for the specific electronic properties or the conformational planarity of the ligands that are key to effective binding with AhR (Denison et al., 2002; Petkov et al., 2010). If the $\mathrm{C}_{14}-\mathrm{C}_{19}$ compounds are indeed lignin dimers, it is reasonable to postulate that the higher AhR activity is partially due to the ability of the dimers to form PAH-like structures from the radical reactions. For example, $\mathrm{C}_{16} \mathrm{H}_{14} \mathrm{O}_{4}$ (Fig. 4, bottom right) is assigned to be (at least partially) a phenanthrene derivative generated from $\beta-5$ dimerization or radical depolymerization reactions and ring closure (Beste, 2014) and may be potent for the induction of AhR - we found a fairly high correlation coefficient $\left(R^{2}=0.65\right.$; Fig. 5$)$. Similarly, other molecular formulas that can be assigned to phenanthrene derivatives $\left(\mathrm{C}_{18} \mathrm{H}_{16} \mathrm{O}_{5}\right.$ and $\left.\mathrm{C}_{18} \mathrm{H}_{16} \mathrm{O}_{6}\right)$ are also positively correlated with AhR activity (both $R^{2}=0.4$ ).

$\mathrm{C}_{14} \mathrm{H}_{12} \mathrm{O}_{3}\left(R^{2}=0.57\right.$, positive effect for $\mathrm{AhR}$ and $R^{2}=$ 0.34 , negative affect on cell toxicity; not shown in Table 2) may be related to the naturally occurring phenol resveratrol, which is a dimer of $\mathrm{H}$ and dihydroxybenzene with a $\beta-1$ linkage. Resveratrol, found in wood in low amounts 
(0.017-0.271 $\mathrm{g} \mathrm{kg}^{-1}$; Tyśkiewicz et al., 2019) and other plant materials, has AhR antagonist activity and may be protective against dioxin (AhR-dependent) toxicity (Casper et al., 1999), consistent with the negative correlation observed here. The lower signal of this ion in our samples prevented a more detailed $\mathrm{MS}^{n}$ study, so the assignment is tentative. However, since this molecule has only alcohol groups, the $\mathrm{H}_{2} \mathrm{O}$ loss we observed in the absence of $\mathrm{CH}_{3} \mathrm{OH}, \mathrm{CO}$, or other labile groups does not contradict the assignment. Some smaller compounds were also positively correlated with AhR activity, with the highest correlation for $\mathrm{C}_{10} \mathrm{H}_{10} \mathrm{O}_{2}\left(R^{2}=0.74\right)$ assigned to methoxy cinnamaldehyde based on its relatively clean $\mathrm{MS}^{2}$ spectrum. The interaction of methoxy cinnamaldehyde with the AhR-responsive gene product CYP1A1 results in its oxidation into an acid (Hasegawa et al., 2002), and it appears to be mainly protective (Cope, 2019). This would be consistent with the observed anticorrelation of this product with cell toxicity $\left(R^{2}=\right.$ 0.42).

Roughly $90 \%$ of the correlations with $\mathrm{MAC}_{\mathrm{vis}}$ are positive in nature, and the positively correlated compounds are fairly diverse, but many have conjugated structures. The conjugation that is observed for lignin phenols (DBE $\sim 5$ ), and even for the observed PAH-like compounds, is insufficient to absorb visible light; however, when relatively small lignin phenols are deprotonated in solution, they absorb light in the visible range due to the resonance stabilization of the phenolates - the red shift is much more pronounced for phenols with extra conjugation such as sinapaldehyde (Panossian et al., 2001). Our solution is not sufficiently basic $(\mathrm{pH} \sim 5)$ for the deprotonated form to substantially exist in equilibrium (e.g., pKa for sinapaldehyde is 8.2 , coniferaldehyde is 7.98, vanillin is 7.4, and bivanillin is 6.16; Ragnar et al., 2000); however, localized charge transfer interactions may facilitate the deprotonation of phenols at $\mathrm{pH}$ much lower than their pKa (Abramovitz and Massey, 1976). It is not clear why sinapaldehyde and coniferaldehyde do not correlate with $\mathrm{MAC}_{\mathrm{vis}}$, but vanillylidene acetone with its additional sigma carbon does. Vanillylidene acetone can achieve some additional resonance with its keto-enol tautomerization (which tends not to happen in the ring because the aromatic phenol is highly favored), while sinapaldehyde and coniferaldehyde cannot. Even so, many of the correlations are not easily understood and could be due to coincidence or driven by unassigned isomers. In the ambient atmosphere, nitrophenols may significantly contribute to wood-burning brown carbon (Mohr et al., 2013; Lin et al., 2017). In this work, these nitrophenols were not observed by GC-MS, so the mechanism of light absorption is likely different. It is possible that charge transfer complexes between neighboring $\mathrm{OH}$ and $\mathrm{C}=\mathrm{O}$ in dimers (e.g., $\mathrm{C}_{18} \mathrm{H}_{18} \mathrm{O}_{6}$; Fig. 4) may be chromophoric, as previously suggested for brown carbon aerosols (Phillips and Smith, 2014). The phenols may also potentially form intermolecular complexes with proton acceptors such as carbonyls or heterocyclic nitrogen species (e.g., $\mathrm{C}_{9} \mathrm{H}_{11} \mathrm{NO}_{4}$ with a pyridine-like $\left(\mathrm{C}_{5} \mathrm{H}_{5} \mathrm{NO}\right)$ loss fragment), as the aerosol species are in close proximity. While no four-ring PAH-like species that would absorb in the visible range (Samburova et al., 2016) were observed in this work, we cannot rule out the possibility that highly conjugated compounds below the detection limit can contribute to light absorption in combination with other chromophores. For the compounds that are correlated with $\mathrm{MAC}_{\mathrm{vis}}$, it is likely that they need to be activated to the ionic form to be chromophoric.

Finally, although composition characterization was not the main focus of this work, we observed some fairly abundant compounds that have not been previously reported. For example, we identified some organic nitrogen compounds as unknown pyridine derivatives (e.g., $\mathrm{C}_{9} \mathrm{H}_{11} \mathrm{NO}_{3}$ ) and nitro or nitrate derivatives (e.g., $\mathrm{C}_{5} \mathrm{H}_{10} \mathrm{~N}_{2} \mathrm{O}_{8}$ ), although in general organic nitrogen is a larger fraction of ambient biomass burning aerosols (Laskin et al., 2009; Lin et al., 2016) than in this study. Poplar WSA also has high abundance peaks that have not been previously observed, e.g., corresponding to the molecular formula $\mathrm{C}_{20} \mathrm{H}_{21} \mathrm{NO}_{3}$ (Fig. 3, dark yellow). Due to the high signal, we assigned $\mathrm{C}_{20} \mathrm{H}_{21} \mathrm{NO}_{3}$ to one or more naturally occurring alkaloids as opposed to being formed from dimerization processes of phenols (plausible monomers should have higher signals than dimers). However, alkaloids that have been extracted from poplar heartwood with the same molecular formula (Chen-Loung et al., 1976; Cordell et al., 1989) do not appear to be entirely consistent with the MS ${ }^{2}$ fragmentation patterns of $\mathrm{C}_{20} \mathrm{H}_{21} \mathrm{NO}_{3}$ in this work (neutral losses $\mathrm{CH}_{3} \mathrm{OH}, \mathrm{C}_{3} \mathrm{H}_{6} \mathrm{O}_{2}$, and $\mathrm{C}_{3} \mathrm{H}_{9} \mathrm{NO}_{3}$ ), suggesting that this compound may be different than previously identified alkaloids or modified from an oxidative process in the smoldering combustion. Poplar WSAs also have a relatively low $\mathrm{EC}_{50}$ value in our cell toxicity study, which is consistent with the higher cell toxicity and genotoxicity response of combustion aerosols from poplar compared to softwood pellets in residential boilers (Kasurinen et al., 2016). Unfortunately, since other types of wood were not studied by Kasurinen et al. (2016), a more thorough comparison cannot be made. As the HRMS correlations require the peaks to be present in most samples for adequate statistics, it is not clear whether the properties of the poplar or other WSA are associated with the uniqueness of their composition rather than commonalities.

\section{Conclusions}

The composition of smoldering WSA generated in the conditions of this work produced abundant lignin and cellulose oxidation and decomposition products that impact aerosol properties in ways that are not easily predictable. We showed that the components of smoldering WSA have high biological activity that can substantially contribute to the environmental health burden of woodsmoke and that these healthrelated effects are not likely PAH-mediated for the smol- 
dering conditions used in this work. The observed bioactivity may be linked to the percent of the fuel that has been burned and thus to the degree of combustion, with more toxic aerosols formed at earlier stages of the burn. It is possible that the more toxic compounds are eventually degraded during the combustion process. These results underscore the importance of untargeted analyses to move beyond well-studied toxicants when considering organic aerosol properties, as the statistical studies identified multiple targets for further toxicological testing. We found that lignin phenols are correlated with visible light absorption (i.e., levoglucosan is anticorrelated) and hypothesize that the mechanism of action is through charge transfer reactions to form phenolates. In atmospheric aerosols, phenolates have been suggested to contribute substantially to brown carbon absorption as facilitated by their charge transfer interactions (Phillips et al., 2017). The lignin percent of wood may also drive toxicity effects, but this remains to be explored. Although some mechanistically probable correlations with bioactivity and light absorption are found in this work, the potential correlations are possibly obscured by isomeric interference at some masses. Future work should add a separation component to the accuratemass and $\mathrm{MS}^{n}$ analysis of WSA for additional clarity. This information will help us understand the contributions of individual components and enhance the value of testing such complex mixtures.

Data availability. Data are available from the corresponding author upon request.

Supplement. The supplement related to this article is available online at: https://doi.org/10.5194/acp-20-539-2020-supplement.

Author contributions. TBN and KQN designed the experiments, and LKC and KQN carried out the experiments. All authors contributed original data and data analyses. LKC, KQN, and TBN prepared the draft paper. All coauthors have reviewed and edited the paper.

Competing interests. The authors declare that they have no conflict of interest.

Financial support. This research has been supported by the National Science Foundation Directorate for Geosciences (grant no. AGS1656889), the National Institute of Environmental Health Sciences (grant no. P42ES004699), and the California Agricultural Experiment Station with funding from the Hatch Act (grant no. CAD-ETX-2345-H) through the USDA National Institute of Food and Agriculture.
Review statement. This paper was edited by Manabu Shiraiwa and reviewed by two anonymous referees.

\section{References}

Abramovitz, A. S. and Massey, V.: Interaction of phenols with old yellow enzyme. Physical evidence for charge-transfer complexes, J. Biol. Chem., 251, 5327-5336, 1976.

Adetona, O., Dunn, K., Hall, D. B., Achtemeier, G., Stock, A., and Naeher, L. P.: Personal $\mathrm{PM}_{2.5}$ exposure among wildland firefighters working at prescribed forest burns in southeastern united states, J. Occup. Environ. Hyg., 8, 503-511, 2011.

Allen-Hoffmann, B. L. and Rheinwald, J. G.: Polycyclic aromatic hydrocarbon mutagenesis of human epidermal keratinocytes in culture, P. Natl. Acad. Sci. USA, 81, 7802-7806, 1984.

Alves, C., Vicente, A., Nunes, T., Gonçalves, C., Fernandes, A. P., Mirante, F., Tarelho, L., de la Campa, A. M. S., Querol, X., and Caseiro, A.: Summer 2009 wildfires in portugal: Emission of trace gases and aerosol composition, Atmos. Environ., 45, 641649, 2011.

Andreae, M. O. and Gelencsér, A.: Black carbon or brown carbon? The nature of light-absorbing carbonaceous aerosols, Atmos. Chem. Phys., 6, 3131-3148, https://doi.org/10.5194/acp-63131-2006, 2006.

Andreae, M. O. and Merlet, P.: Emission of trace gases and aerosols from biomass burning, Global Biogeochem. Cy., 15, 955-966, 2001.

Atkinson, R.: Atmospheric chemistry of VOCs and $\mathrm{NO}_{x}$, Atmos. Environ., 34, 2063-2101, 2000.

Badertscher, M., Bischofberger, K., Munk, M. E., and Pretsch, E.: A novel formalism to characterize the degree of unsaturation of organic molecules, J. Chem. Inf. Comp. Sci., 41, 889-893, https://doi.org/10.1021/ci000135o, 2001.

Barron, M. G., Heintz, R., and Rice, S. D.: Relative potency of pahs and heterocycles as aryl hydrocarbon receptor agonists in fish, Mar. Environ. Res., 58, 95-100, 2004.

Bartoňková, I. and Dvořák, Z.: Essential oils of culinary herbs and spices display agonist and antagonist activities at human aryl hydrocarbon receptor AhR, Food Chem. Toxicol., 111, 374-384, 2018.

Baston, D. S. and Denison, M. S.: Considerations for potency equivalent calculations in the ah receptor-based calux bioassay: Normalization of superinduction results for improved sample potency estimation, Talanta, 83, 1415-1421, 2011.

Beardsell, I., Bell, S., Robinson, S., and Rumbold, H.: Mcem part a: Mcqs, Royal Society of Medicine Press, Boca Raton, FL, USA, 2009.

Bertschi, I., Yokelson, R. J., Ward, D. E., Babbitt, R. E., Susott, R. A., Goode, J. G., and Hao, W. M.: Trace gas and particle emissions from fires in large diameter and belowground biomass fuels, J. Geophys. Res., 108, 8472, https://doi.org/10.1029/2002JD002100, 2003.

Beste, A.: Reaxff study of the oxidation of lignin model compounds for the most common linkages in softwood in view of carbon fiber production, J. Phys. Chem. A, 118, 803-814, 2014.

Billiard, S. M., Timme-Laragy, A. R., Wassenberg, D. M., Cockman, C., and Di Giulio, R. T.: The role of the aryl hydrocarbon receptor pathway in mediating synergistic developmental toxi- 
city of polycyclic aromatic hydrocarbons to zebrafish, Toxicol. Sci., 92, 526-536, 2006.

Bølling, A. K., Pagels, J., Yttri, K. E., Barregard, L., Sallsten, G., Schwarze, P. E., and Boman, C.: Health effects of residential wood smoke particles: The importance of combustion conditions and physicochemical particle properties, Part. Fibre Toxicol., 6, 29, https://doi.org/10.1186/1743-8977-6-29, 2009.

Bølling, A. K., Totlandsdal, A. I., Sallsten, G., Braun, A., Westerholm, R., Bergvall, C., Boman, J., Dahlman, H. J., Sehlstedt, M., and Cassee, F.: Wood smoke particles from different combustion phases induce similar pro-inflammatory effects in a co-culture of monocyte and pneumocyte cell lines, Part. Fibre Toxicol., 9, 45, https://doi.org/10.1186/1743-8977-9-45, 2012.

Bolton, J. L. and Dunlap, T.: Formation and biological targets of quinones: Cytotoxic versus cytoprotective effects, Chem. Res. Toxicol., 30, 13-37, 2016.

Boman, B. C., Forsberg, A. B., and Järvholm, B. G.: Adverse health effects from ambient air pollution in relation to residential wood combustion in modern society, Scandinavian Journal of Work, Environment \& Health, 29, 251-260, 2003.

Brennan, J. C., Bassal, A., He, G., and Denison, M. S.: Development of a recombinant human ovarian (fbg1) cell line containing estrogen receptor $\alpha$ and $\beta$ for improved detection of estrogenic/antiestrogenic chemicals, Environ. Toxicol. Chem., 35, 91-100, 2016.

Burns, R. M. and Honkala, B. H.: Silvics of north america, United States Department of Agriculture, Washington, D.C., USA, 1990.

Carey, D. G., Schwarz, L. A., Pliego, G. J., and Raymond, R. L.: Respiratory rate is a valid and reliable marker for the anaerobic threshold: Implications for measuring change in fitness, J. Sport. Sci. Med., 4, 482-488, 2005.

Casper, R. F., Quesne, M., Rogers, I. M., Shirota, T., Jolivet, A., Milgrom, E., and Savouret, J.-F.: Resveratrol has antagonist activity on the aryl hydrocarbon receptor: Implications for prevention of dioxin toxicity, Mol. Pharmacol., 56, 784-790, 1999.

Chen, Q., Wang, M., Wang, Y., Zhang, L., Li, Y., and Han, Y.: Oxidative potential of water-soluble matter associated with chromophoric substances in $\mathrm{PM}_{2.5}$ over xi'an, china, Environ. Sci. Technol., 53, 8574-8584, 2019.

Chen, Y. and Bond, T. C.: Light absorption by organic carbon from wood combustion, Atmos. Chem. Phys., 10, 1773-1787, https://doi.org/10.5194/acp-10-1773-2010, 2010.

Chen-Loung, C., Hou-Min, C., and Cowling, E. B.: Aporphine alkaloids and lignans in heartwood of liriodendron tulipifera, Phytochemistry, 15, 547-550, 1976.

Chowdhury, Z., Le, L. T., Masud, A. A., Chang, K. C., Alauddin, M., Hossain, M., Zakaria, A., and Hopke, P. K.: Quantification of indoor air pollution from using cookstoves and estimation of its health effects on adult women in northwest bangladesh, Aerosol Air Qual. Res., 12, 463-475, 2012.

Christensen, E., Evans, R. J., and Carpenter, D.: High-resolution mass spectrometric analysis of biomass pyrolysis vapors, J. Anal. Appl. Pyrol., 124, 327-334, 2017.

Cipolletti, M., Solar Fernandez, V., Montalesi, E., Marino, M., and Fiocchetti, M.: Beyond the antioxidant activity of dietary polyphenols in cancer: The modulation of estrogen receptors (ers) signaling, Int. J. Mol. Sci., 19, 2624, https://doi.org/10.3390/ijms19092624, 2018.
Clemons, J. H., Allan, L. M., Marvin, C. H., Wu, Z., McCarry, B. E., Bryant, D. W., and Zacharewski, T. R.: Evidence of estrogen- and tcdd-like activities in crude and fractionated extracts of $\mathrm{PM}_{10}$ air particulate material using in vitro gene expression assays, Environ. Sci. Technol., 32, 1853-1860, 1998.

Cope, R. B.: Toxicology and drug interactions of nutraceuticals, in: Nutraceuticals in veterinary medicine, Springer, Cham, Switzerland, 711-727, 2019.

Cordell, G. A., Southon, I. W., and Buckingham, J.: Dictionary of alkaloids, Chapman and Hall, Boca Raton, FL, USA, 1989.

Cupitt, L. T., Glen, W. G., and Lewtas, J.: Exposure and risk from ambient particle-bound pollution in an airshed dominated by residential wood combustion and mobile sources, Environ. Health Persp., 102, 75-84, 1994.

Danielsen, P. H., Møller, P., Jensen, K. A., Sharma, A. K., Wallin, H. k., Bossi, R., Autrup, H., Mølhave, L., Ravanat, J.-L., and Briedé, J. J.: Oxidative stress, DNA damage, and inflammation induced by ambient air and wood smoke particulate matter in human a549 and thp-1 cell lines, Chem. Res. Toxicol., 24, 168-184, 2011.

DeGroot, D., He, G., Fraccalvieri, D., Bonati, L., Pandini, A., and Denison, M. S.: Ahr ligands: Promiscuity in binding and diversity in response, in: The Ah receptor in biology and toxicology, John Wiley \& Sons, Hoboken, New Jersey, USA, 63-79, 2011.

Denison, M. and Heath-Pagliuso, S.: The ah receptor: A regulator of the biochemical and toxicological actions of structurally diverse chemicals, B. Environ. Contam. Tox., 61, 557-568, 1998.

Denison, M. S. and Nagy, S. R.: Activation of the aryl hydrocarbon receptor by structurally diverse exogenous and endogenous chemicals, Annu. Rev. Pharmacol., 43, 309-334, 2003.

Denison, M. S., Pandini, A., Nagy, S. R., Baldwin, E. P., and Bonati, L.: Ligand binding and activation of the ah receptor, Chem.-Biol. Interact., 141, 3-24, 2002.

Denison, M. S., Soshilov, A. A., He, G., DeGroot, D. E., and Zhao, B.: Exactly the same but different: Promiscuity and diversity in the molecular mechanisms of action of the aryl hydrocarbon (dioxin) receptor, Toxicol. Sci., 124, 1-22, 2011.

Edye, L. A. and Richards, G. N.: Analysis of condensates from wood smoke. Components derived from polysaccharides and lignins, Environ. Sci. Technol., 25, 1133-1137, 1991.

Einfeld, W., Ward, D. E., and Hardy, C.: Effects of fire behavior on prescribed fire smoke characteristics: A case study, chap. 50, in: Global biomass burning: Atmospheric, climatic, and biospheric implications, edited by: Levine, J. S., MIT Press, Cambridge, MA, USA, 412-419, 1991.

EPA: Air quality criteria for particulate matter, fourth external review draft, Office of Research and Development, NCFEA, editor. EPA/600/p-99/002aD and bD, US EPA, Research Triangle Park, NC, USA, 2003.

Ezzati, M. and Kammen, D. M.: The health impacts of exposure to indoor air pollution from solid fuels in developing countries: Knowledge, gaps, and data needs, Environ. Health Persp., 110, 1057-1068, 2002.

Figueiredo, A. R., Campos, F., de Freitas, V., Hogg, T., and Couto, J. A.: Effect of phenolic aldehydes and flavonoids on growth and inactivation of oenococcus oeni and lactobacillus hilgardii, Food Microbiol., 25, 105-112, 2008.

Flannigan, M. and Harrington, J.: A study of the relation of meteorological variables to monthly provincial area burned by wildfire in canada (1953-80), J. Appl. Meteorol., 27, 441-452, 1988. 
Fleming, L. T., Lin, P., Laskin, A., Laskin, J., Weltman, R., Edwards, R. D., Arora, N. K., Yadav, A., Meinardi, S., Blake, D. R., Pillarisetti, A., Smith, K. R., and Nizkorodov, S. A.: Molecular composition of particulate matter emissions from dung and brushwood burning household cookstoves in Haryana, India, Atmos. Chem. Phys., 18, 2461-2480, https://doi.org/10.5194/acp18-2461-2018, 2018.

Franko, J., Jackson, L. G., Hubbs, A., Kashon, M., Meade, B., and Anderson, S. E.: Evaluation of furfuryl alcohol sensitization potential following dermal and pulmonary exposure: Enhancement of airway responsiveness, Toxicol. Sci., 125, 105-115, 2011.

Galati, G. and O'brien, P. J.: Potential toxicity of flavonoids and other dietary phenolics: Significance for their chemopreventive and anticancer properties, Free Radical Bio. Med., 37, 287-303, 2004.

Goñi, M. A. and Hedges, J. I.: Lignin dimers: Structures, distribution, and potential geochemical applications, Geochim. Cosmochim. Ac., 56, 4025-4043, 1992.

Gorin, C. A., Collett Jr., J. L., and Herckes, P.: Wood smoke contribution to winter aerosol in fresno, ca, J. Air Waste Manage., 56, 1584-1590, 2006.

Graglia, M., Kanna, N., and Esposito, D.: Lignin refinery: Towards the preparation of renewable aromatic building blocks, ChemBioEng Reviews, 2, 377-392, 2015.

Guillén, M. D. and Ibargoitia, M. L.: Gc/ms analysis of lignin monomers, dimers and trimers in liquid smoke flavourings, J. Sci. Food Agr., 79, 1889-1903, 1999.

Hasegawa, A., Yoshino, M., Nakamura, H., Ishii, I., Watanabe, T., Kiuchi, M., Ishikawa, T., Ohmori, S., and Kitada, M.: Identification of inhibitory component in cinnamon - omethoxycinnamaldehyde inhibits cyp1a2 and cyp2e1, Drug Metab. Pharmacok., 17, 229-236, 2002.

He, G., Zhao, J., Brennan, J. C., Affatato, A. A., Zhao, B., Rice, R. H., and Denison, M. S.: Cell-based assays for identification of aryl hydrocarbon receptor (ahr) activators, in: Optimization in drug discovery, Springer, Totowa, NJ, USA, 221-235, 2014.

Hedberg, E., Kristensson, A., Ohlsson, M., Johansson, C., Johansson, P.-̊., Swietlicki, E., Vesely, V., Wideqvist, U., and Westerholm, R.: Chemical and physical characterization of emissions from birch wood combustion in a wood stove, Atmos. Environ., 36, 4823-4837, 2002.

Himmelsbach, D. S. and Barton, F. E.: Carbon-13 nuclear magnetic resonance of grass lignins, J. Agr. Food Chem., 28, 1203-1208, 1980.

Hosoya, T., Kawamoto, H., and Saka, S.: Cellulose-hemicellulose and cellulose-lignin interactions in wood pyrolysis at gasification temperature, J. Anal. Appl. Pyrol., 80, 118-125, 2007 a.

Hosoya, T., Kawamoto, H., and Saka, S.: Pyrolysis behaviors of wood and its constituent polymers at gasification temperature, J. Anal. Appl. Pyrol., 78, 328-336, 2007 b.

Hoydonckx, H., Van Rhijn, W., Van Rhijn, W., De Vos, D., and Jacobs, P.: Furfural and derivatives, Ullmann's Encyclopedia of Industrial Chemistry, Hoboken, New Jersey, USA, 2000.

Ingemarsson, Å., Nilsson, U., Nilsson, M., Pedersen, J. R., and Olsson, J. O.: Slow pyrolysis of spruce and pine samples studied with gc/ms and gc/ftir/fid, Chemosphere, 36, 2879-2889, 1998.

Irulegi, O., Serra, A., and Hernández, R.: Data on records of indoor temperature and relative humidity in a university building, Data in brief, 13, 248-252, 2017.
Kasurinen, S., Jalava, P. I., Uski, O., Happo, M. S., Brunner, T., Mäki-Paakkanen, J., Jokiniemi, J., Obernberger, I., and Hirvonen, M.-R.: Toxicological characterization of particulate emissions from straw, miscanthus, and poplar pellet combustion in residential boilers, Aerosol. Sci. Tech., 50, 41-51, 2016.

Kendrick, E.: Mass scale based on $\mathrm{ch}_{2}=14.0000$ for highresolution mass spectrometry of organic compounds, Anal. Chem., 35, 2146-2154, 1963.

Kind, T. and Fiehn, O.: Seven golden rules for heuristic filtering of molecular formulas obtained by accurate mass spectrometry, BMC Bioinformatics, 8, 105, https://doi.org/10.1186/14712105-8-105, 2007.

Kirchstetter, T. W. and Thatcher, T. L.: Contribution of organic carbon to wood smoke particulate matter absorption of solar radiation, Atmos. Chem. Phys., 12, 6067-6072, https://doi.org/10.5194/acp-12-6067-2012, 2012.

Kleeman, M. J., Riddle, S. G., Robert, M. A., Jakober, C. A., Fine, P. M., Hays, M. D., Schauer, J. J., and Hannigan, M. P.: Source apportionment of fine (pm1.8) and ultrafine (pm0.1) airborne particulate matter during a severe winter pollution episode, Environ. Sci. Technol., 43, 272-279, 2008.

Krüger, T., Long, M., and Bonefeld-Jørgensen, E. C.: Plastic components affect the activation of the aryl hydrocarbon and the androgen receptor, Toxicology, 246, 112-123, 2008.

Kubátová, A., Dronen, L. C., Picklo, M. J., and Hawthorne, S. B.: Midpolarity and nonpolar wood smoke particulate matter fractions deplete glutathione in raw 264.7 macrophages, Chem. Res. Toxicol., 19, 255-261, 2006.

Lao, X. Q., Zhang, Z., Lau, A. K., Chan, T.-C., Chuang, Y. C., Chan, J., Lin, C., Guo, C., Jiang, W. K., and Tam, T.: Exposure to ambient fine particulate matter and semen quality in taiwan, Occup. Environ. Med., 75, 148-154, 2018.

Laskin, A., Smith, J. S., and Laskin, J.: Molecular characterization of nitrogen-containing organic compounds in biomass burning aerosols using high-resolution mass spectrometry, Environ. Sci. Technol., 43, 3764-3771, 2009.

Lee, J. S., Lippman, S. M., Benner, S. E., Lee, J. J., Ro, J. Y., Lukeman, J. M., Morice, R. C., Peters, E. J., Pang, A. C., and Fritsche Jr, H. A.: Randomized placebo-controlled trial of isotretinoin in chemoprevention of bronchial squamous metaplasia, J. Clin. Oncol., 12, 937-945, 1994.

Lewis, C. W., Baumgardner, R. E., Stevens, R. K., Claxton, L. D., and Lewtas, J.: Contribution of woodsmoke and motor vehicle emissions to ambient aerosol mutagenicity, Environ. Sci. Technol., 22, 968-971, 1988.

Lewtas, J.: Air pollution combustion emissions: Characterization of causative agents and mechanisms associated with cancer, reproductive, and cardiovascular effects, Mutat. Res./Reviews in Mutation Research, 636, 95-133, 2007.

Li, Z., Zhang, H., Gibson, M., and Li, J.: An evaluation on combination effects of phenolic endocrine disruptors by estrogen receptor binding assay, Toxicol. in Vitro, 26, 769-774, 2012.

Lin, P., Aiona, P. K., Li, Y., Shiraiwa, M., Laskin, J., Nizkorodov, S. A., and Laskin, A.: Molecular characterization of brown carbon in biomass burning aerosol particles, Environ. Sci. Technol., 50, 11815-11824, 2016.

Lin, P., Bluvshtein, N., Rudich, Y., Nizkorodov, S. A., Laskin, J., and Laskin, A.: Molecular chemistry of atmospheric brown car- 
bon inferred from a nationwide biomass burning event, Environ. Sci. Technol., 51, 11561-11570, 2017.

Lin, Y.-C., Cho, J., Tompsett, G. A., Westmoreland, P. R., and Huber, G. W.: Kinetics and mechanism of cellulose pyrolysis, J. Phys. Chem. C, 113, 20097-20107, 2009.

Machala, M., Vondráček, J., Bláha, L., Ciganek, M., and Neča, J.: Aryl hydrocarbon receptor-mediated activity of mutagenic polycyclic aromatic hydrocarbons determined using in vitro reporter gene assay, Mutat. Res./Genetic Toxicology and Environmental Mutagenesis, 497, 49-62, 2001.

MacMillan, D. K. and Murphy, R. C.: Analysis of lipid hydroperoxides and long-chain conjugated keto acids by negative ion electrospray mass spectrometry, J. Am. Soc. Mass Spectr., 6, 11901201, 1995.

Maga, J. and Chen, Z.: Pyrazine composition of wood smoke as influenced by wood source and smoke generation variables, Flavour Frag. J., 1, 37-42, 1985.

Mandal, P. K.: Dioxin: A review of its environmental effects and its aryl hydrocarbon receptor biology, J. Comp. Physiol. B, 175, 221-230, 2005

Mazzoleni, L. R., Zielinska, B., and Moosmüller, H.: Emissions of levoglucosan, methoxy phenols, and organic acids from prescribed burns, laboratory combustion of wildland fuels, and residential wood combustion, Environ. Sci. Technol., 41, 21152122, 2007.

McKenzie, L. M., Hao, W. M., Richards, G. N., and Ward, D. E.: Quantification of major components emitted from smoldering combustion of wood, Atmos. Environ., 28, 3285-3292, 1994.

Menon, P.: Indoor spatial monitoring of combustion generated pollutants (tsp, co, and bap) by indian cookstoves, Hawaii University Department of Meteorology, Honolulu, HI, USA, 1988.

Mohr, C., Lopez-Hilfiker, F. D., Zotter, P., Prévôt, A. S. H., Xu, L., Ng, N. L., Herndon, S. C., Williams, L. R., Franklin, J. P., Zahniser, M. S., Worsnop, D. R., Knighton, W. B., Aiken, A. C., Gorkowski, K. J., Dubey, M. K., Allan, J. D., and Thornton, J. A.: Contribution of nitrated phenols to wood burning brown carbon light absorption in detling, united kingdom during winter time, Environ. Sci. Technol., 47, 6316-6324, 2013.

Moosmüller, H., Chakrabarty, R. K., Ehlers, K. M., and Arnott, W. P.: Absorption Ångström coefficient, brown carbon, and aerosols: basic concepts, bulk matter, and spherical particles, Atmos. Chem. Phys., 11, 1217-1225, https://doi.org/10.5194/acp11-1217-2011, 2011.

Moran-Mendoza, O., Pérez-Padilla, J., Salazar-Flores, M., and Vazquez-Alfaro, F.: Wood smoke-associated lung disease: A clinical, functional, radiological and pathological description, Int. J. Tuberc. Lung D., 12, 1092-1098, 2008.

Morawska, L. and Zhang, J. J.: Combustion sources of particles. 1. Health relevance and source signatures, Chemosphere, 49, 10451058, 2002.

Naeher, L. P., Brauer, M., Lipsett, M., Zelikoff, J. T., Simpson, C. D., Koenig, J. Q., and Smith, K. R.: Woodsmoke health effects: A review, Inhal. Toxicol., 19, 67-106, 2007.

Nebert, D. W., Roe, A. L., Dieter, M. Z., Solis, W. A., Yang, Y., and Dalton, T. P.: Role of the aromatic hydrocarbon receptor and [Ah] gene battery in the oxidative stress response, cell cycle control, and apoptosis, Biochem. Pharmacol., 59, 65-85, 2000.

Nebert, D. W., Dalton, T. P., Okey, A. B., and Gonzalez, F. J.: Role of aryl hydrocarbon receptor-mediated induction of the CYP1 enzymes in environmental toxicity and cancer, J. Biol. Chem., 279, 23847-23850, 2004.

Neugebauer, P., Bonnekoh, B., Wevers, A., Michel, O., Mahrle, G., Krieg, T., and Stennert, E.: Human keratinocyte culture from the peritonsillar mucosa, Eur. Arch. Oto-Rhino-L., 253, 245-251, 1996.

Nguyen, L. P. and Bradfield, C. A.: The search for endogenous activators of the aryl hydrocarbon receptor, Chem. Res. Toxicol., 21, 102-116, 2007.

Novák, J., Hilscherová, K., Landlová, L., Čupr, P., Kohút, L., Giesy, J. P., and Klánová, J.: Composition and effects of inhalable size fractions of atmospheric aerosols in the polluted atmosphere. Part II. In vitro biological potencies, Environ. Int., 63, 64-70, 2014.

Nunes, C. A., Lima, C. F., Barbosa, L. C., Colodette, J. L., Gouveia, A., and Silvério, F. O.: Determination of eucalyptus spp lignin s/g ratio: A comparison between methods, Bioresource Technol., 101, 4056-4061, 2010.

NYSERDA: Assessment of carbonaceous $\mathrm{PM}_{2.5}$ for new york and the region, Albany, NY, USA, 2008.

Nyström, R., Lindgren, R., Avagyan, R., Westerholm, R., Lundstedt, S., and Boman, C.: Influence of wood species and burning conditions on particle emission characteristics in a residential wood stove, Energ. Fuel., 31, 5514-5524, 2017.

Ohlemiller, T.: Smoldering combustion, SFPE Handbook Of Fire Protection Engineering, New York, NY, USA, 3, 2002.

Oros, D. R. and Simoneit, B. R.: Identification and emission factors of molecular tracers in organic aerosols from biomass burning part 1. Temperate climate conifers, Appl. Geochem., 16, 15131544, 2001a.

Oros, D. R. and Simoneit, B. R.: Identification and emission factors of molecular tracers in organic aerosols from biomass burning part 2. Deciduous trees, Appl. Geochem., 16, 1545-1565, $2001 \mathrm{~b}$.

Orozco-Levi, M., Garcia-Aymerich, J., Villar, J., RamirezSarmiento, A., Anto, J., and Gea, J.: Wood smoke exposure and risk of chronic obstructive pulmonary disease, Eur. Respir. J., 27, 542-546, 2006.

Panossian, A., Mamikonyan, G., Torosyan, M., Gabrielyan, E., and Mkhitaryan, S.: Analysis of aromatic aldehydes in brandy and wine by high-performance capillary electrophoresis, Anal. Chem., 73, 4379-4383, 2001.

Park, J., Shigenaga, M. K., and Ames, B. N.: Induction of cytochrome P4501A1 by 2, 3, 7, 8-tetrachlorodibenzo-p-dioxin or indolo $(3,2-b)$ carbazole is associated with oxidative DNA damage, P. Natl. Acad. Sci. USA, 93, 2322-2327, 1996.

Park, R. J., Jacob, D. J., and Logan, J. A.: Fire and biofuel contributions to annual mean aerosol mass concentrations in the united states, Atmos. Environ., 41, 7389-7400, 2007.

Patterson, E. M. and McMahon, C. K.: Absorption characteristics of forest fire particulate matter, Atmos. Environ., 18, 2541-2551, 1984.

Petkov, P., Rowlands, J., Budinsky, R., Zhao, B., Denison, M., and Mekenyan, O.: Mechanism-based common reactivity pattern (corepa) modelling of aryl hydrocarbon receptor binding affinity, SAR QSAR Environ. Res., 21, 187-214, 2010.

Phillips, S. M. and Smith, G. D.: Light absorption by charge transfer complexes in brown carbon aerosols, Environ. Sci. Technol. Lett., 1, 382-386, 2014. 
Phillips, S. M., Bellcross, A. D., and Smith, G. D.: Light absorption by brown carbon in the southeastern united states is phdependent, Environ. Sci. Technol., 51, 6782-6790, 2017.

Pińol, J., Terradas, J., and Lloret, F.: Climate warming, wildfire hazard, and wildfire occurrence in coastal eastern spain, Climatic Change, 38, 345-357, 1998.

Plamenac, P., Nikulin, A., Pikula, B., and Marković, Z.: Cytologic changes in the respiratory tract in children smokers, Acta Cytol., 23, 389-391, 1979a.

Plamenac, P., Nikulin, A., Pikula, B., and Vujanić, G.: Cytologic changes of the respiratory tract as a consequence of air pollution and smoking, Acta Cytol., 23, 449-453, 1979b.

Rabelo, E., Veras, C., Carvalho Jr., J., Alvarado, E., Sandberg, D., and Santos, J.: Log smoldering after an amazonian deforestation fire, Atmos. Environ., 38, 203-211, 2004.

Ragnar, M., Lindgren, C. T., and Nilvebrant, N.-O.: Pka-values of guaiacyl and syringyl phenols related to lignin, J. Wood Chem. Technol., 20, 277-305, 2000.

Rhee, K. S. and Bratzler, L.: Polycyclic hydrocarbon composition of wood smoke, J. Food Sci., 33, 626-632, 1968.

Rhim, J.: Neoplastic transformation of human epithelial cells in vitro, Anticancer Res., 9, 1345-1365, 1989.

Rice, R. H. and Green, H.: Presence in human epidermal cells of a soluble protein precursor of the cross-linked envelope: Activation of the cross-linking by calcium ions, Cell, 18, 681-694, 1979.

Rice, R. H., Steinmann, K. E., DeGraffenried, L. A., Qin, Q., Taylor, N., and Schlegel, R.: Elevation of cell cycle control proteins during spontaneous immortalization of human keratinocytes, Mol. Biol. Cell, 4, 185-194, 1993.

Roach, P. J., Laskin, J., and Laskin, A.: Higher-order mass defect analysis for mass spectra of complex organic mixtures, Anal. Chem., 83, 4924-4929, 2011.

Rogers, M. S., Kobayashi, T., Pittelkow, M. R., and Strehler, E. E.: Human calmodulin-like protein is an epithelial-specific protein regulated during keratinocyte differentiation, Exp. Cell Res., 267, 216-224, 2001.

Rogge, W. F., Hildemann, L. M., Mazurek, M. A., Cass, G. R., and Simoneit, B. R.: Sources of fine organic aerosol. 9. Pine, oak, and synthetic log combustion in residential fireplaces, Environ. Sci. Technol., 32, 13-22, 1998.

Salonvaara, M., Ojanen, T., Holm, A., Künzel, H. M., and Karagiozis, A. N.: Moisture buffering effects on indoor air qualityexperimental and simulation results, Proceedings (CD) of the Performance of Exterior Envelopes of Whole Buildings IX International Conference, 5-10 December 2004, Clearwater Beach, FL, USA, 11, 2004.

Samburova, V., Connolly, J., Gyawali, M., Yatavelli, R. L. N., Watts, A. C., Chakrabarty, R. K., Zielinska, B., Moosmüller, H., and Khlystov, A.: Polycyclic aromatic hydrocarbons in biomassburning emissions and their contribution to light absorption and aerosol toxicity, Sci. Total Environ., 568, 391-401, 2016.

Selevan, S. G., Borkovec, L., Slott, V. L., Zudová, Z., Rubes, J., Evenson, D. P., and Perreault, S. D.: Semen quality and reproductive health of young czech men exposed to seasonal air pollution, Environ. Health Persp., 108, 887-894, 2000.

Shafizadeh, F. and Fu, Y.: Pyrolysis of cellulose, Carbohyd. Res., 29, 113-122, 1973.
Sharma, R. K. and Hajaligol, M. R.: Effect of pyrolysis conditions on the formation of polycyclic aromatic hydrocarbons (PAHs) from polyphenolic compounds, J. Anal. Appl. Pyrol., 66, 123144, 2003.

Simoneit, B. R.: Biomass burning - a review of organic tracers for smoke from incomplete combustion, Appl. Geochem., 17, 129$162,2002$.

Simoneit, B. R., Rogge, W., Mazurek, M., Standley, L., Hildemann, L., and Cass, G.: Lignin pyrolysis products, lignans, and resin acids as specific tracers of plant classes in emissions from biomass combustion, Environ. Sci. Technol., 27, 2533-2541, 1993.

Simoneit, B. R., Schauer, J. J., Nolte, C., Oros, D. R., Elias, V. O., Fraser, M., Rogge, W., and Cass, G. R.: Levoglucosan, a tracer for cellulose in biomass burning and atmospheric particles, Atmos. Environ., 33, 173-182, 1999.

Simoneit, B. R., Rogge, W., Lang, Q., and Jaffé, R.: Molecular characterization of smoke from campfire burning of pine wood (pinus elliottii), Chemosphere-Global Change Science, 2, 107-122, 2000.

Smith, J. S., Laskin, A., and Laskin, J.: Molecular characterization of biomass burning aerosols using high-resolution mass spectrometry, Anal. Chem., 81, 1512-1521, 2008.

Smith, K. R. and Mehta, S.: The burden of disease from indoor air pollution in developing countries: Comparison of estimates, Int. J. Hyg. Envir. Heal., 206, 279-289, 2003.

Smith, P. K., Krohn, R. I., Hermanson, G., Mallia, A., Gartner, F., Provenzano, M., Fujimoto, E., Goeke, N., Olson, B., and Klenk, D.: Measurement of protein using bicinchoninic acid, Anal. Biochem., 150, 76-85, 1985.

Standley, L. J. and Simoneit, B. R.: Preliminary correlation of organic molecular tracers in residential wood smoke with the source of fuel, Atmos. Environ. B-Urb., 24, 67-73, 1990.

Stejskalova, L., Dvorak, Z., and Pavek, P.: Endogenous and exogenous ligands of aryl hydrocarbon receptor: Current state of art, Curr. Drug Metab., 12, 198-212, https://doi.org/10.2174/138920011795016818, 2011.

Swiston, J. R., Davidson, W., Attridge, S., Li, G. T., Brauer, M., and van Eeden, S. F.: Wood smoke exposure induces a pulmonary and systemic inflammatory response in firefighters, Eur. Respir. J., 32, 129-138, 2008.

Tyśkiewicz, K., Konkol, M., Kowalski, R., Rój, E., Warmiński, K., Krzyżaniak, M., Gil, Ł., and Stolarski, M. J.: Characterization of bioactive compounds in the biomass of black locust, poplar and willow, Trees, 33, 1235-1263, 2019.

Updyke, K. M., Nguyen, T. B., and Nizkorodov, S. A.: Formation of brown carbon via reactions of gaseous ammonia with secondary organic aerosols from biogenic and anthropogenic precursors, Atmos. Environ., 63, 22-31, 2012.

US EPA: Method 610: Polynuclear aromatic hydrocarbons, Washington, D.C., USA, 2005.

van der Hage, E. R., Boon, J. J., Steenvoorden, R. J., and Weeding, T. L.: Resonance-enhanced multiphoton ionization mass spectrometric analysis of lignin using laser pyrolysis with entrainment into a supersonic jet, Anal. Chem., 66, 543-550, 1994.

Wang, J., Xie, P., Xu, Y., Kettrup, A., and Schramm, K.-W.: Differing estrogen activities in the organic phase of air particulate matter collected during sunny and foggy weather in a chinese 
city detected by a recombinant yeast bioassay, Atmos. Environ., 38, 6157-6166, 2004.

Ward, D., Susott, R., Kauffman, J., Babbitt, R., Cummings, D., Dias, B., Holben, B., Kaufman, Y., Rasmussen, R., and Setzer, A.: Smoke and fire characteristics for cerrado and deforestation burns in brazil: Base-b experiment, J. Geophys. Res., 97, 1460114619, 1992.

Washenfelder, R., Attwood, A., Brock, C., Guo, H., Xu, L., Weber, R., Ng, N., Allen, H., Ayres, B., and Baumann, K.: Biomass burning dominates brown carbon absorption in the rural southeastern united states, Geophys. Res. Lett., 42, 653-664, 2015.

Watts, H. D., Mohamed, M. N. A., and Kubicki, J. D.: Comparison of multistandard and tms-standard calculated $\mathrm{nmr}$ shifts for coniferyl alcohol and application of the multistandard method to lignin dimers, J. Phys. Chem. B, 115, 1958-1970, 2011.

Wegesser, T. C., Pinkerton, K. E., and Last, J. A.: California wildfires of 2008: Coarse and fine particulate matter toxicity, Environ. Health Persp., 117, 893-897, 2009.

Wenger, D., Gerecke, A. C., Heeb, N. V., Hueglin, C., Seiler, C., Haag, R., Naegeli, H., and Zenobi, R.: Aryl hydrocarbon receptor-mediated activity of atmospheric particulate matter from an urban and a rural site in switzerland, Atmos. Environ., 43, 3556-3562, 2009a.

Wenger, D., Gerecke, A. C., Heeb, N. V., Schmid, P., Hueglin, C., Naegeli, H., and Zenobi, R.: In vitro estrogenicity of ambient particulate matter: Contribution of hydroxylated polycyclic aromatic hydrocarbons, J. Appl. Toxicol., 29, 223-232, $2009 \mathrm{~b}$.

Whetten, R. and Sederoff, R.: Lignin biosynthesis, Plant Cell, 7, 1001-1013, 1995.
White, R. H.: Effect of lignin content and extractives on the higher heating value of wood, Wood Fiber Sci., 19, 446-452, 2007.

WHO: The world health report 2002: Reducing risks, promoting healthy life, World Health Organization, Geneva, Switzerland, 2002.

WHO: Indoor air pollution and health, fact sheet 292, Geneva, Switzerland, 2011.

Wilson, M. J., Sabbioni, G., Rando, R., and Miller III, C. A.: Activation of aryl hydrocarbon receptor signaling by extracts of teak and other wood dusts, Environ. Toxicol., 30, 1375-1384, 2015.

Wu, J., Winer, A. M., and Delfino, R. J.: Exposure assessment of particulate matter air pollution before, during, and after the 2003 southern california wildfires, Atmos. Environ., 40, 3333-3348, 2006.

Wu, L., Jin, L., Shi, T., Zhang, B., Zhou, Y., Zhou, T., Bao, W., Xiang, H., Zuo, Y., and Li, G.: Association between ambient particulate matter exposure and semen quality in wuhan, china, Environ. Int., 98, 219-228, 2017.

Yokelson, R. J., Susott, R., Ward, D. E., Reardon, J., and Griffith, D. W.: Emissions from smoldering combustion of biomass measured by open-path fourier transform infrared spectroscopy, J. Geophys. Res., 102, 18865-18877, 1997.

Zelikoff, J. T., Chen, L. C., Cohen, M. D., and Schlesinger, R. B.: The toxicology of inhaled woodsmoke, J. Toxicol. Env. Heal. B, 5, 269-282, 2002

Zhang, Y., Obrist, D., Zielinska, B., and Gertler, A.: Particulate emissions from different types of biomass burning, Atmos. Environ., 72, 27-35, 2013. 